\title{
Risk Reporting of the Banking Sector of Bangladesh: A Time Horizon Analysis
}

\author{
Niluthpaul Sarker (Corresponding author) \\ School of Management, Huazhong University of Science and Technology \\ 1037 Luoyu Road, Hongshan District, Wuhan 430074, P.R.China
}

Tel: 86-13-12-518-4590Ｅ-mail: niluthpaul@yahoo.com

Dr. Shamsun Nahar

Department of Accounting \& Information Systems, Jagannath University

9-10, Chittaranjan Avenue, Dhaka 1100, Dhaka, Bangladesh

Tel: 88-019-1104-7956_E-mail: snahar8079@yahoo.com

\author{
Received: Feb. 12, $2018 \quad$ Accepted: April 26, $2018 \quad$ Published: June 1, 2018 \\ doi:10.5296/ajfa.v10i1.12804 URL: https://doi.org/10.5296/ajfa.v10i1.12804
}

\begin{abstract}
The study focused on the practical scenarios of bank risk disclosures where it is assumed that adequate risk disclosures expand the path of transparency in the marketplace. The reason is that the financial disclosures, including risk items, represent their image of the current and potential investors, and can impact their mentality about investment. The research analyzed the credit risk, market risk and operational risk reporting intensities in their reports. It is noted that the maximum Risk Weighted Assets (RWA) are held for credit risk of the banking system whereas the remaining part of the system utilized by the market risk and operational risk. It is found that the risk for the top five (5) or the top ten (10) banks is extremely high. The concentration symptom of risk is not good as the fewer borrowers occupied the most of the credit.
\end{abstract}

Keywords: Bank Risk, Disclosures, Bangladesh

JEL Classifications: G21; G32. 


\section{Introduction}

Risk disclosure is the most contemporary issue debated in the developed and developing economy. In corporate financial reporting, risk disclosure is widening the path of transparency in the marketplace. The reason is that financial disclosures along with risk items represents the image of the banks to their current and prospective investors and can affect their mindset. In every step of operation, it should be remembered that transparency acted as the key point of accounting and investment Practice (Abraham and Cox, 2007). In fact, information is disclosed in the annual reports due to minimizing the gaps of asymmetric information. The benefits of disclosing the risk related information are not only for shareholders, analysts, investors, but also extended to other stakeholders (Lajili and Zeghal, 2005). Linsley and Shrives (2005b) notified that the distorted facts or unimportant information in the disclosure may not ensure transparency.

The quality of voluntary disclosure of primary sources of corporate communication in the annual report is at the heart of modern financial reporting. The confidence of a lack of investors lags behind the failure of companies in the main global companies. The credibility crisis, coupled with the threat of terrorist attacks on businesses and the global financial crisis, has led to calls for better disclosure of information, making sensible investment decisions. As a result, the Annual Enterprise report is no longer focused on account-quantitative information, but on the qualitative information of volunteers on a variety of topics, such as corporate risk. Voluntary risk disclosure can be defined as an amateur confession by the enterprises on corporate strategy, firm characteristics, business operations, and other external factors that may affect expected outcomes of the company.

\section{Classification of Bank Risk}

The risk may be defined as the product of uncertainties associated with the imperfection of human knowledge and incapability of human reasoning (Habibullah and Ghosh, 1986) (Note 1). One can narrow down the boundaries of uncertainties and define the future through better information and better comprehension. Apparently, the risk is the uncertainty that exists about the occurrence of some events. In the banking sector, the mandatory unit held for the risk management as Risk Management Unit (RMU). The risk generated in the banking entity is not obviously by the internal factors but also extended to the external forces. Sometimes the risk management process is called the four (4) step process, and it differs by service rendered. However the risk can be broken down into six (6) generic types (namely): systematic or market risk, credit risk, counterparty risk, liquidity risk, operational risk, and legal risks. The Table below presents the clarification of each type of risk: 


\section{Macrothink}

Table 1. Ramifications of bank risk

\begin{tabular}{|c|c|c|}
\hline $\mathbf{S N}$ & Risk & Definition \\
\hline 1. & Market Risk & $\begin{array}{l}\text { The risk arising from the movement of prices and have an adverse effect on } \\
\text { bank performance. }\end{array}$ \\
\hline \multirow[t]{3}{*}{2.} & Credit Risk & $\begin{array}{l}\text { The risk adversely affects the bank asset because of selecting the lower } \\
\text { quality of borrowers or counterparties. }\end{array}$ \\
\hline & & $\begin{array}{l}\checkmark \text { The loss initiated from the decreased value of credit quality where } \\
\text { the default is the extreme situation. }\end{array}$ \\
\hline & & $\begin{array}{l}\checkmark \text { Sometimes, bank use credit risk as an issue when they deferred the } \\
\text { payment obligation }\end{array}$ \\
\hline 3. & Liquidity Risk & $\begin{array}{l}\text { The loss arises due to the increase of operating cycle or interruption in cash } \\
\text { conversion cycle. }\end{array}$ \\
\hline 4. & Operational Risk & $\begin{array}{l}\text { The most significant cause of lost generation from the weak internal control } \\
\text { system and governance system. } \\
\checkmark \quad \text { Intentional misstatement } \\
\checkmark \quad \text { Model risk (using the wrong pricing model, for instance) } \\
\checkmark \quad \text { Human Factor }\end{array}$ \\
\hline 5. & Legal and Regulatory Risk & $\begin{array}{l}\text { The abolishment of enacted rules or any prohibitedactivities that are not } \\
\text { valid in the eye of law. } \\
\checkmark \quad \text { Transactions that are voided due to lack of appropriate licenses. } \\
\checkmark \quad \text { Changes in Tax Laws }\end{array}$ \\
\hline
\end{tabular}

In general, the risk classification depends on the context or scenarios may differ and very tough to express quantitatively. Therefore, bank risks based on types that are disclosed and quantifiable are primarily focused on four distinct types of risk (Hitchins et al., 2001). These are presented below:

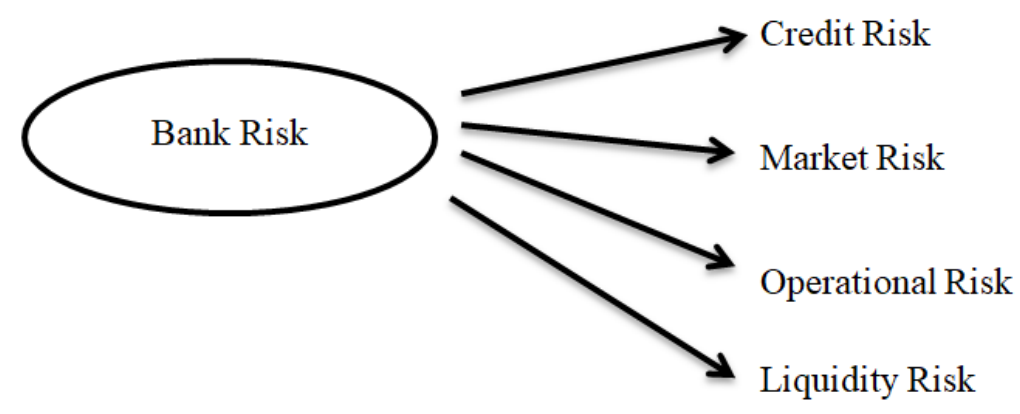

Figure 1. The Principal components of Bank Risk 
However, in the case of this study, risk classification is most appropriately adapted for the banking sector is the guidance of IFRS 7. By IFRS 7, the risk of the financial institutions is comprisedof Credit risk, Market risk, and Liquidity risk.

\subsection{Credit risk}

Credit risk is very important and significant ramification of bank risk (Lin, 2009; Bonfim 2009, Angelini et al., 2008; Richared, 2008; Al-Tamimi and Al-Mazrooei, 2007). It creates in a position where the borrower is unable to pay the installment as well as interest. Here the most important discussion is the selection of quality borrower. It is true that banks are the intermediaries where they take a deposit from the people in a small pool but invest in a large volume, the net interest is their main source of income. So the parties, like depositors and borrowers should keep in the same line and give more effort in collecting loans. It is found that more than $50 \%$ or risk arising from credit risk.

Over the years, most of the banks in the country's public and private sector have aggressive banking. In the last six months, private banks have disbursed loans at the double the rate of deposit growth. This has created a crisis of liquidity or cash in most of the private banks of the country. In this situation, the decision to reduce the debt-deposit ratio or the capital adequacy ratio has been decided.

The main function of the bank is to distribute loans to customers from deposits. In this case, if the general public of the country can collect BDT 100 then the maximum loan of BDT 85 can be given. However, Islamic banks can lend money up to BDT 90. But most of the private banks have recently passed 90 percent of AD ratio. As a result, most of the private banks have created liquidity or cash crisis. In this situation, the bankers strictly ordered the commercial banks to refrain from aggressive investments in the bankers meeting. After the circular issue from the Bangladesh Bank, the new rate of ED ratio will be determined. This rate may be more than 80 percent for the general banks and 85 percent for the Islamic banks. The rates will be determined by excluding cash deposits (CRRs) and statutory deposits (SLRs) in the central bank. Banks have been asked to prepare the matter from now on. It is found that huge amount of credit has been distributed among the banks recently. It has been discussed whether the delivery of the loan has gone in the appropriate sector. Deposit rates have not been deposited at the rate of interest. As a result, the AD ratio of the banks increased. Bangladesh Bank said 85 percent of the AD would not be able to live in any bank.

For the country's existing GDP growth, 15-16 percent of the loan growth in the private sector is sufficient. But in recent times the private sector credit growth grew from 19 to 20 percent. Bangladesh Bank does not think it is in line with the situation. Country's import expenditure has increased over the past year in comparison, export earnings and remittance did not increase. As a result, there is a shortage of current fund. There is a discussion about how the deficit can be overcome. Increasing the quality of the loan and raising the loan for the import of quality products, instead of increasing the distribution of luxury goods, should be followed. 


\subsection{Market Risk}

Market risk is "the risk related to the uncertainty of a financial institution's earnings on its trading portfolio caused by changes in market conditions such as the price of an asset, interest rates, market volatility, and market liquidity" (Saunders, Chapter 10). Bank exposed the market risk in different ways. Generally, it categories into two heads based on the situations, where the volatility of similar assets are affected by systematic risk in the financial markets; alternatively the individual asset is affected by specific risk ( Apostolik et al. 2009). In the banking industry, four (4) common types of market risk are found which are: Interest Rate Risk (IRR), Foreign Exchange Rate Risk (EER), Equity Price Risk (EPR) and lastly commodities risk (Apostolik et al., 2009; Jorion, 2003; and Greuning and Bratanovic, 2003). The market risk measurement is very important, because:

a) Management Decision: The strategic level employee wants market risk related information for better and decision making.

b) Limit setup: Market risk information helps in target setting or position limits.

c) Utilization of Resources: Market risk profile compares and contrast the risk and return tradeoff in each asset class and help to keep sufficient capital for the risky assets.

d) Performance judgment: The risk-return composition easily identified the less risky projects and can set the real benefit scheme.

e) The effectiveness of regulation: The internal rating based techniques can ensure superior capital allotment.

\subsection{Liquidity risk}

Liquidity risk concept is inherently involved with the financial risk in the contemporary banking system. In fact, the shortage of liquid assets makes the banks more vulnerable as banks involved with loan grants and further investments which cannot be extended due to fund crisis. Though, different research outcomes based on different categories of bank risk but all of them are interlinked with one another. The logic behind this inefficient credit approval or unworthy investment initiated the future liquidity crisis that leads to the higher market risk due to lower performance and higher volatility of return. After the global financial crisis, the practitioner, regulators and market participants are more concern about the liquidity crisis and tried to update the existing standards with incorporating preventive measures for bank liquidity crunch.

\subsubsection{Liquidity Risk Component:}

Banks liquidity thresholds categorize the core components of liquidity risk based on meeting the liquidity using assets conversion or funds creation. The types of liquidity risk are exposed with the purpose of the banks. These are:

i) Firstly, banks are leveling the liquidity risk by liquidity risk management practice within the banks and termed it as an idiosyncratic risk. It is found that good corporate culture is incorporating strong liquidity risk management and exposed to lower idiosyncratic risk. 
ii) Secondly, the liquidity risk involved with the maturity of assets that influence the market. In fact, the mismatch in market liquidity grounds the higher propensity to fund crisis in the bank. However, the liquidity disruption affects the market negatively due to inconsistent waves of cash-flows.

\subsubsection{Liquidity Risk under Basel III}

According to BASEL III (Section 8.1.3.4), Liquidity risk can be defined by maturity or cash conversion cycle. When given security or asset is failed to trade quickly in the market to avoid probable losses or unable to acquire obligatory profit or the bank is fall in a position where they could not fulfill the commitments in time or the payment to creditors become due, then it is called liquidity risk. Liquidity risk is categorized into two types:

\section{Funding Liquidity Risk (FLR)}

II. Market Liquidity Risk (MLR)

Table 2. Compare and contrast of Liquidity Risk

\begin{tabular}{|c|c|c|c|}
\hline S.N. & Subject & FLR & MLR \\
\hline 1. & Definition & $\begin{array}{l}\text { Funding Liquidity Risk (FLR) is the risk } \\
\text { where a bank is failed to meet its current } \\
\text { obligation or loss future cash flows. }\end{array}$ & $\begin{array}{l}\text { Market Liquidity Risk (MLR) is the risk } \\
\text { where a bank falls in a position where } \\
\text { they cannot easily offset or sell position } \\
\text { without incurring a loss. }\end{array}$ \\
\hline 2. & Subject Matter & Liquidity & Illiquidity \\
\hline 3. & Indicator & Current Ratio; Quick Ratio & $\begin{array}{l}\text { Bid-Ask-Spread (Width); Position Size; } \\
\text { Resiliency }\end{array}$ \\
\hline 4. & Dimension & $\begin{array}{l}\text { The ability of a financial entity to raise } \\
\text { cash by borrowing on either an } \\
\text { unsecured or a secured basis. }\end{array}$ & $\begin{array}{l}\text { Market liquidity as the cost - both in } \\
\text { expense and time - of buying or selling } \\
\text { an asset for cash. }\end{array}$ \\
\hline 5. & Declining effect & $\begin{array}{l}\text { If funding liquidity declines because of } \\
\text { market stress, for example, this may } \\
\text { cause intermediaries to become less } \\
\text { willing to provide market liquidity. }\end{array}$ & $\begin{array}{l}\text { Declines in market liquidity, in turn, } \\
\text { may further impair funding liquidity, } \\
\text { creating negative feedback dynamic. }\end{array}$ \\
\hline 6. & Relationship & $\begin{array}{l}\text { When market liquidity is drying up (i.e., } \\
\text { is low), funding liquidity risk is high }\end{array}$ & $\begin{array}{l}\text { High funding liquidity risk is associated } \\
\text { with high market liquidity risk }\end{array}$ \\
\hline
\end{tabular}

\section{Empirical Studies}

In the Asian region, corporate disclosure requirements and transparency took keen attention of the regulators after the financial crisis in 1997. The crisis bears negative effects on the investors' choice resulting international investors were reluctant to their lending decisions in favor of developing countries. At that time, IMF took a proactive role to recover the economic meltdown of the affected countries and also forced to enact transparency in financial reporting system (Fung, 2014). Researchers are not only emphasized on disclosure 
transparency but also encouraged to develop a culture of transparency in the organization (Bennis and O' Toole, 2009).

Baumann and Nier (2004) found that banks with more disclosures have lower stock volatility compared to the banks those disclose less information. These findings also confirm the "Stakeholder theory" which states the greater amount of disclosure affirms rational choice of users and inversely affect the bank risk. Risk disclosure reduced information asymmetry and noticed both the informed and uninformed investors (Poskitt, 2005). However, Linsley and Shives (2005) concluded that disclosures itself never be transparent when there is a lack of useful information. The prudent users take effective decisions based on market signals about the bank's financial position and performance. The high quality of disclosure can make it possible only by fair presentation of the statements. Critically examining the market signal in due time, banks took corrective measures to reduce risk exposure (Oliveira et al., 2011).

Healy, P.M. and Palepu, K.G. (2001) explained the role of disclosures in the modern capital market. They found that corporate disclosure is a function of the efficient capital market. They showed that asymmetric information creates noise in the investment decision and increase the cost of capital. The reason is that investors claim a high rate of premium for their investment in an unknown scenario. The following Figure 2shows the financial and information flows in the economy:

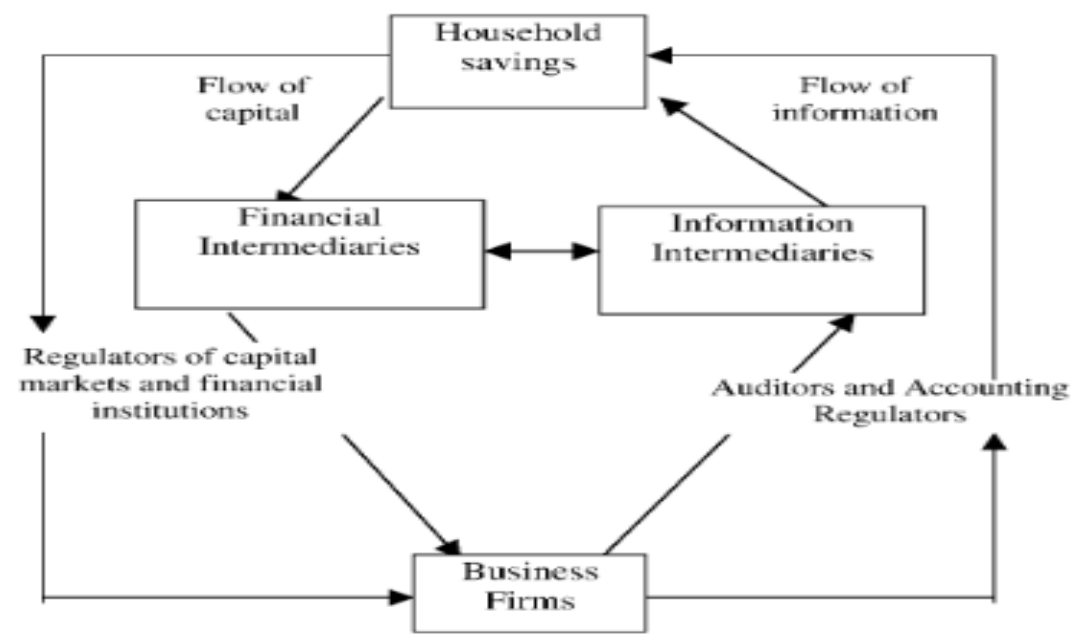

Source: Healy, P.M. and Palepu, K.G. (2001)

Figure 2. Financial and information flows in a capital market economy

The above scenario depicts that financial intermediaries are directly connected with all sectors. It is also vital in the ordinary course of sense that economy is controlled by its interactive response. The efficient market hypothesis states that all the available information is reflected in the current market price. That is why; information is a more powerful tool in the economy. Now a day, private information is traded for the sake of replicating fact and safeguarding predicted decisions.

Due to the regulatory pressure, publicly listed companies mandatorily produce different reports as the requirement and compliance. The financial institutions like banks are in the 
position of intermediary that deals with the small depositor and large lender, so the demand for disclosures is higher to settle their position stable. By the Pillar 3 of Basel norm, the banking sector should disclose risk-related information as a compliance basis and will be monitored by the owner and regulators so that the conflicts between the management and shareholders can be minimized. Most of the evidencesupport in favor of the adequate disclosure practice of banks as it positively affects the stability of banks, though some of the authors have doubt. Jensen and Meckling (1976) initially addressed the need for disclosure in the moral hazard problem on the grounds of ownership and control. The reason is that the outside shareholders have the right to know all the relevant information happened within the business organization and based on this information they are evaluating the performance and take their decision whether they hold the share or release it. In fact, the adequate level of disclosures removes the conflict and confusion from the mind of the shareholder and mitigate agency problem. In the case of the banking sector, a significant part of their liabilities isshort-term obligations. So the release of appropriate information can strictly monitor the risk-taking behavior of banks which led to the depositors in their deposit decision whether they keep it or withdraw the money that may face higher cost of funding (Cordella and Yeyati, 1998, Botosan \& Plumlee, 2002; Bertay, Demicgüç-Kunt \& Huizinga, 2013). Disclosure is not only reduced the risk-taking incentives but also control the probability of bank failure.

Several studies (Fischer, 1999; Nier, 2005; Tadesse, 2006) showed the evidence that banking crisis initiated not only by the risk absorption but also the lack of bank transparency and both are caused due to information asymmetry. It is also found that banks that are disclosed more information to the public regarding their risk is in a better position (Baumann and Nier, 2004). On the other hand, Nier (2005) revealed that bank's transparent disclosures eliminate financial problems and reduce risk experience that reflects the image in the stock market and controls the volatility of share price. The study provided a composite set of disclosure indices which contain seventeen items under four broad heads, e.g. (i) Assets (ii) Liabilities (iii) Memo lines and (iv) Income Statement and considered those indices as a measure of transparency.

However, Nier and Baumann (2006) found that the banks that provide more disclosure to the public are more transparent that is the indication of strong market discipline and are encouraged to avoid risk. It also found that the disclosures effect became obsolete or in diminishing trends when the bank failure supported by the government. Sometimes, government prioritizes the political agendas rather than the economic consequences and make bound to the government-owned banks to release or grant loans to some unproductive sectors. Though, a higher level of disclosures may be found unproductive for transparency when the cost related to information production and dissemination is more than the benefit achieved from this information. The key problem identified of corporate disclosure is the weakening in a strategic fight with the competitor as the competitor get all the information and can set appropriate strategy for his business or exploit can affect the competitors (Hyytinen and Takalo, 2003). It is also argued that bank stability is greatly influenced by the transparency of banks (Tadesse, 2006). According to “disclosure-fragility' view, it is assumed that negligible amount of distorted facts may misguide the depositors or lose public confidence. This view 
ignores the fact that banking business is reliant on public trust. Prior studies conducted by Gilbert and Vaugan (1998), Kaufman and Scott (2003), Gorton \& Huang (2006) revealed that more disclosures could act negatively in bank stability where any specific problem identified and generalized for the baking sector as a whole that will create panic. Furthermore, disclosure sometimes distorted the investor's mind and fall their confidence level that led to bank failure rather than used as a monitoring tool (Tadesse, 2006). In fact, the psychology of the investor differs concerning the positive and negatives news of the business.

Another finding extracted from Bushee and Noe (2000) that firms with a large volume of institutional investors required more disclosure to reduce the monitoring cost. The reason behind this, higher disclosure has negative effect on stock price volatility as it decreases information asymmetry. The findings also revealed that lower variance of share price could draw the attention of the investor as well as external sources that result in thelower cost of capital. Some of the studies (Healy and Palepu, 2001; Hassan \& Marston, 2010) found that investors those do not have direct access to the privately generated information are mostly depend on public information. Therefore, assuming other things remaining constant, investors select banks that have a higher level of disclosure.

In the above discussion, it is found that the effects of disclosure on bank risk are debatable and to some extent conflicting. However, agency theory advocates in favor of higher disclosure as it mitigates the conflict of interest and controls the risk-takingbehavior of banks. Banks should have stringent disclosure requirement as its nature is more opaque than other industries. The disclosure stability theory depicts that higher disclosure and transparency allow the investors to stay longer period in the structure of strong market discipline. It could happen by proper allocation of assets and elimination of asymmetric information in the marketplace among the participants.

In fact, investors can evaluate the performance of banks accurately in the presence of adequate disclosures. It is true that the funding cost of the risky banks is more than the less risky banks as the association with the probability of default is more. Therefore, the banks those provide higher disclosures are more transparent pursue lower risk strategies. On the contrary, banks with higher level of disclosures may create a noise where important information may be covered by unimportantinformation.

To conclude, it is found that the effect of disclosures on bank risk (Overall risk, Credit risk, Market risk, and Liquidity risk) may be either positive or negative. It is also argued that disclosures and corporate governance havestrong positive relation, so banks governance system also responsible for the riskiness of banks.

\section{Risk Reporting of the Banking Sector of Bangladesh: A Time Horizon Analysis}

The introduction to risk and objectives of risk management are describedby the guidelines issued by Bangladesh Bank (Note 2) under section Forty-Five (Section 45) of "Bank Companies Act, 1991". It provides a systematic way of identifying and measuring potential risk for the sake of diversifying and preventing their impact on bank performance. From February 2012, Bangladesh bank implemented the guidelines mandatorily for all the 
scheduled banks operated in Bangladesh. The "Risk Management Guidelines for Banks" are structured by following aspects:

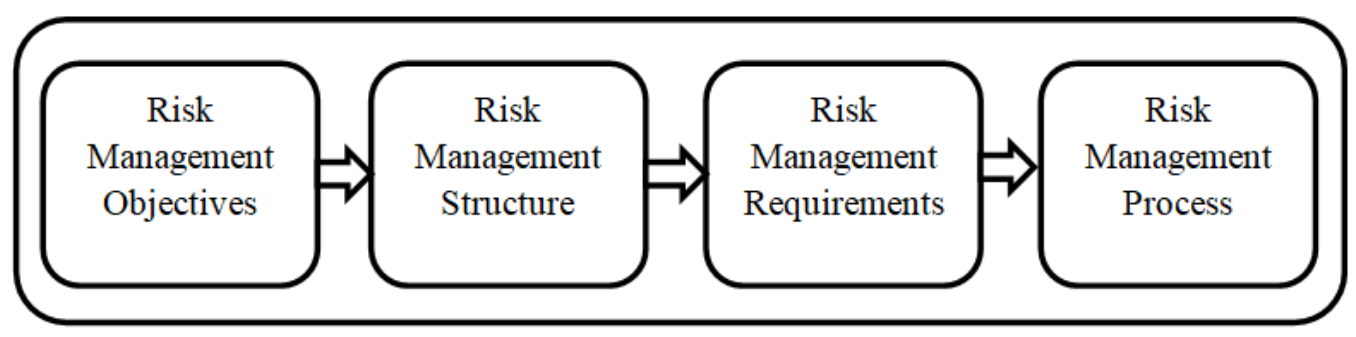

Figure 3. Aspects of Risk Management Guidelines for Banks

Source: Risk Management Guidelines for Banks (2012), Department of Off-site Supervision, Bangladesh Bank

The guidelines of the above-stated structure are setby the prescribed framework issued by Basel Committee on Banking Supervision (BCBS) in October 2006. The requirements of the core principles (CP) in "Risk Management Processes" is the identifying, evaluating, monitoring and controlling or mitigating risk and also estimate the capital adequacy requirements to cover up the probable risk profile. The processes start with the size and riskiness of banks in the premises of credit risk, market risk, liquidity risk, operational risk, and interest rate risk.

In the Table 3 below categorized the banks in five (5) groups based on the ranges and performances of banks with their experiences, like, Group 1 ( Private commercial banks), Group 2 (State-owned and Private commercial banks under special attention), Group 3 (Full-fledged Islamic Private commercial banks), Group 4 (Foreign Commercial Banks), and Group 5 (Fourth Generation Private Commercial Banks). The new forms of bank categories are used in bank risk analysis that is significantly apart from traditional form. The prospect of new look appears considering financial health and orientation:

Table 3. Group of Banks

\begin{tabular}{cl}
\hline Bank Group & Description of the group \\
\hline Group 1 & $\begin{array}{l}\text { Private commercial banks } \\
\text { Group 2 }\end{array}$ \\
& $\begin{array}{l}\text { State-owned and Private commercial banks under special attention } \\
\text { (Note 3) }\end{array}$ \\
Group 3 & Full-fledged Islamic Private commercial banks \\
Group 4 & Foreign Commercial Banks \\
Group 5 & Fourth Generation (Note 4) Private Commercial Banks \\
\hline
\end{tabular}

The Table 4 below presents the share in total banking assets (\%) concerningnumber of banks in each bank group. The time series data contains the year of 2014, 2015 and 2016 with five (5) groups of banks. In the case of number of banks, it is found that Group 1 includes twenty-two (22) private commercial banks; Group 2 includes ten (10) State-owned and Private commercial banks under special attention; Group 3 includes seven (7)Full-fledged 
Islamic Private commercial banks; Group 4 includes nine (9) Foreign Commercial Banks, and Group 5 includes nine (9) Fourth Generation Private Commercial Banks in the year 2016. The deviation found only in the case of Fourth generation private commercial banks where the number of banks is eight (8) in the year of 2014 and 2015.Again, in the case of share in total banking sector assets, it is found that Group 1(Private commercial banks) possesses $44 \%$ in the year 2014 and 2015, and 43.4\%, in the year 2016; Group 2 (State-owned and Private commercial banks under special attention) possesses $32 \%, 31 \%$, and $30.6 \%$ subsequent to the year 2014, 2015 and 2016; Group 3 (Full-fledge Islamic Private commercial banks) kept its share $18 \%$ in both of the years 2014 and 2015 but slightly increase in 2015 which is $18.4 \%$; Group 4 (Foreign Commercial Banks) hold their share in total banking sector assets in a decreasing trends which are $6 \%$ in the year 2014, 5\% in the year 2015 and $4.8 \%$ in the year 2016; and lastly Group 5 hold their portion at 2\% in the year 2014 and 2015 but $2.9 \%$ in the year 2016 which showed slightly increasing trend compared with previous years.

Table 4. Grouping of Banks for risk analysis

\begin{tabular}{cllcc}
\hline Year & $\begin{array}{l}\text { Bank } \\
\text { Group }\end{array}$ & Description of the group & $\begin{array}{c}\text { No. of } \\
\text { Banks }\end{array}$ & $\begin{array}{c}\text { Share in total } \\
\text { banking sector } \\
\text { assets (\%) }\end{array}$ \\
\hline $\mathbf{2 0 1 6}$ & Group 1 & Private commercial banks & 22 & 43.4 \\
& Group 2 & State-owned and Private commercial banks under special attention & 10 & 30.6 \\
& Group 3 & Full-fledged Islamic Private commercial banks & 7 & 18.4 \\
& Group 4 & Foreign Commercial Banks & 9 & 4.8 \\
& Group 5 & Fourth Generation Private Commercial Banks & 9 & 2.9 \\
$\mathbf{2 0 1 5}$ & Group 1 & Private commercial banks & 22 & 44 \\
& Group 2 & State-owned and Private commercial banks under special attention & 10 & 31 \\
& Group 3 & Full-fledged Islamic Private commercial banks & 7 & 18 \\
& Group 4 & Foreign Commercial Banks & 9 & 5 \\
& Group 5 & Fourth Generation Private Commercial Banks & 8 & 2 \\
$\mathbf{2 0 1 4}$ & Group 1 & Private commercial banks & 22 & 44 \\
& Group 2 & State-owned and Private commercial banks under special attention & 10 & 32 \\
& Group 3 & Full-fledged Islamic Private commercial banks & 7 & 18 \\
& Group 4 & Foreign Commercial Banks & 9 & 6 \\
& Group 5 & Fourth Generation Private Commercial Banks & 8 & 2 \\
\hline
\end{tabular}

\subsection{The overall risk profile of the banking sector}

The chart below showed the trends of risk-weighted asset density ratio over the period of 2013 to 2016 with group comparison. The Risk Weighted Asset Density ratio is defined by the quick and simple clarification or measures of bank's on-balance sheet and off-balance sheet exposure in the market. Although there is a stiff criticism of RWA Density ratio due to its substantial divergence across banksand inconsistent application in risk management process through jurisdictions. However, omitting the individual effect, the study considers the banking industry as a whole under uniform authorities that may give more accurate results. In the year 2013, it is found that Group 4 (Foreign Commercial Banks) has the highest 
risk-weighted asset density ratio which is $85.40 \%$ whereas the lowest position attained by Group 5 (Fourth Generation Private Commercial Banks). The second position took by Group 1 (Private commercial banks) with $82.95 \%$ of RWA Density Ratio, but Group 2 (State-owned and Private commercial banks under special attention) and Group 3 (Full-fledged Islamic Private commercial banks) lies on average point with $54.10 \%$ and $66.73 \%$. In the year 2014 , the phenomenon is same for all groups except Group 5 those have higher RWADR (Risk Weighted Asset Density Ratio) in comparison with previous year. However, in the year 2015, Group 1 stood highest position with $80.08 \%$ of RWADR and Group 4 and Group 5 jointly possessed the second position with $78 \%$. The position of Group 2 is worse within the groups which are $49.30 \%$ and have gradual decreasing trends. Finally, in the year 2016, the major finding is the decreasing trends of Group 2 (State-owned and Private commercial banks under special attention) which has $77.1 \%$. In the case of the industry average, it is revealed that the trend is the downward slope and most importantly Group 2 and Group 3 in all cases lie below the average line. So, there is a need for taking care of the two groups otherwise the average industry risk will increase.

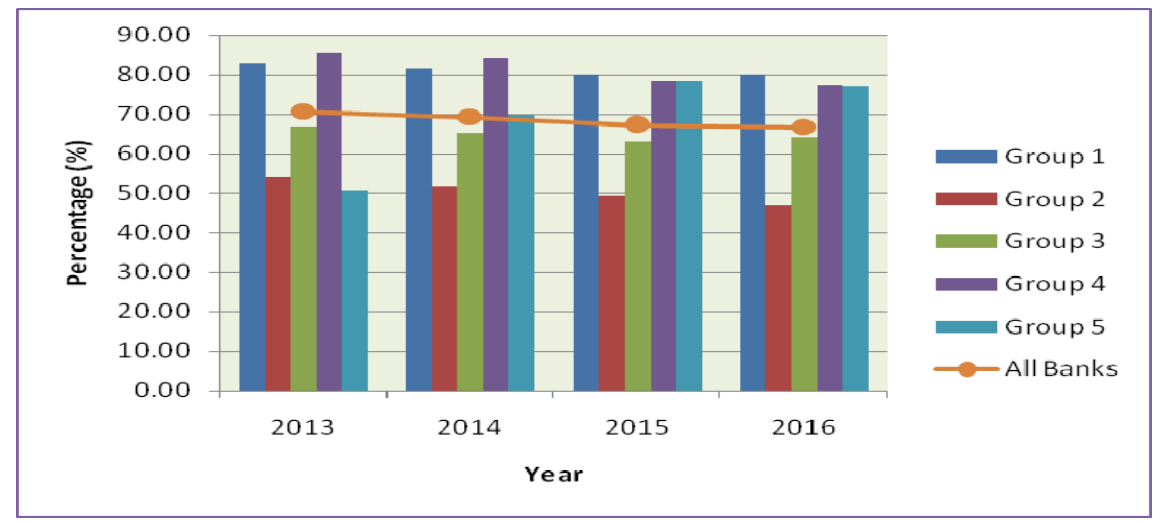

Chart 1. Risk Weighted Asset Density Ratio

\subsection{Banking sector risk structure under Basel III}

The regulatory authority, Bangladesh Bank, the central bank of Bangladesh, provides specific guidelines for risk reporting standards under Basel III accord. It is found that all of the banks report their credit risk, market risk as well as operational risk in their annual report. The trend of the risk structure is shown in the following chart. The findings are very interesting and valuable for the relevant users. The reason is that the concern parties can take their decisions giving priorities on the risk exposure. It is notable that among the three risk categories the major portion occupied by the credit risk exposure of banks. In 2016, it is revealed that the weighted risk asset (RWA) was mostly attributed to credit risk which was $87.20 \%$ of a total risk-weighted asset of the baking system whereas the remaining portion consumed by market risk and operational risk at $3.80 \%$ and $9.0 \%$ as well. 


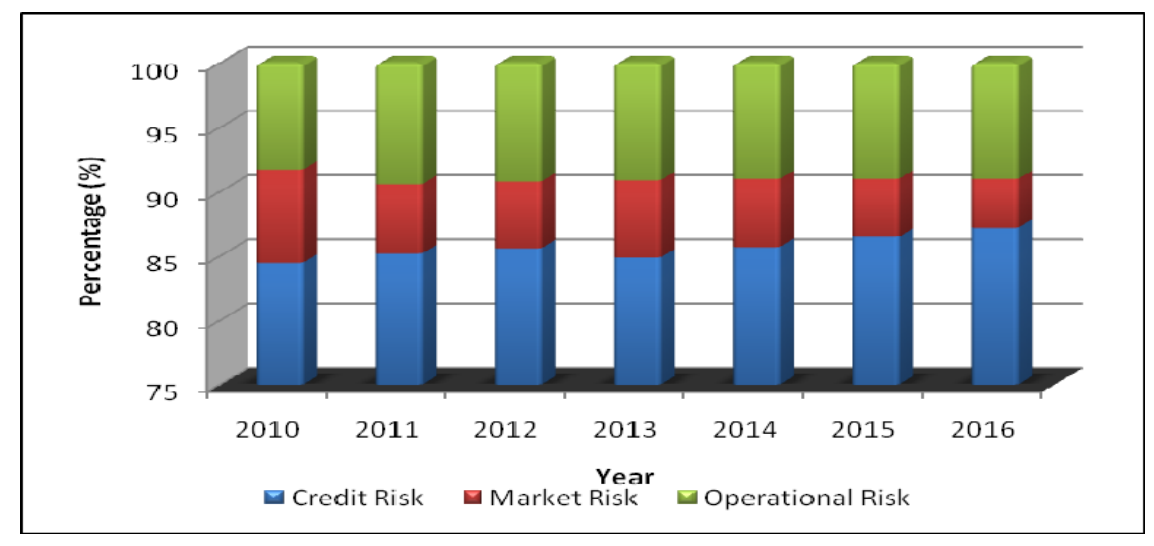

Chart 2. Banking sector Risk Structure in Bangladesh

\subsection{Credit Risk disclosures under Basel III}

The credit risk is defined by the probability of loss or non-recovery of loans generating from loans grants causes by the counterparties for their unwillingness or inabilities that results in the breach of contract. The Chart below showed the structure of credit risk which is segregated as Balance Sheet Risk and Off-Balance Sheet Risk. The study found that the balance sheet risk is significantly higher than the off-balance sheet risk. The trends of the balance sheet risk showed the upward slope from 2010 to 2016 which were ranges from $85.4 \%$ to $87.60 \%$. However, the blessing thing is the decreasing trend of Off-Balance Sheet Risk during the period of 2010 to 2016 with $14.60 \%$ to $12.40 \%$. The enforcement of Basel norms is restraining the banks from off-balance sheet activities. Regarding the regulatory capital, banking sector remains in the same position in compare with the previous year. Although the capital to risk-weighted ratio was $10.80 \%$ at the end of 2016 , it was lower by four (4) basis points contrast with the most recent year. The deterioration is not for the fall of credit quality but for the shift of regulatory framework which shifts from Basel II to Basel III accord. There was an improvement in non-performing loan rate in comparison with the previous year and also decreasing the required provisions on loan defaults. In Basel III, the calculation of regulatory capital is stringier. Under the new framework, the eligible capital determination process is slightly changed where deferred tax assets and revaluation reserve (20\% per year) are excluded, and only a specific percentage of the general provision was allowed to include. The sought of deductions reduce the eligible capital in compared with weighted risk assets. The study concludes that the increasing trend of credit risk overlooks the capital regulation due to weak governance system. In the case of a Non-performing loan, the trend is very disappointed which showed a growing trend from the year 2015 to 2016 at the rate of $8.80 \%$ to $9.20 \%$. It is also found that the weighted risk asset (RWA) amount allocated for credit risk was BDT 7754.4 billion for both balance sheet and off-balance sheet exposure whereas BDT 299.7 billion kept for operational risk and BDT 696.4 billion were kept for market risk. 


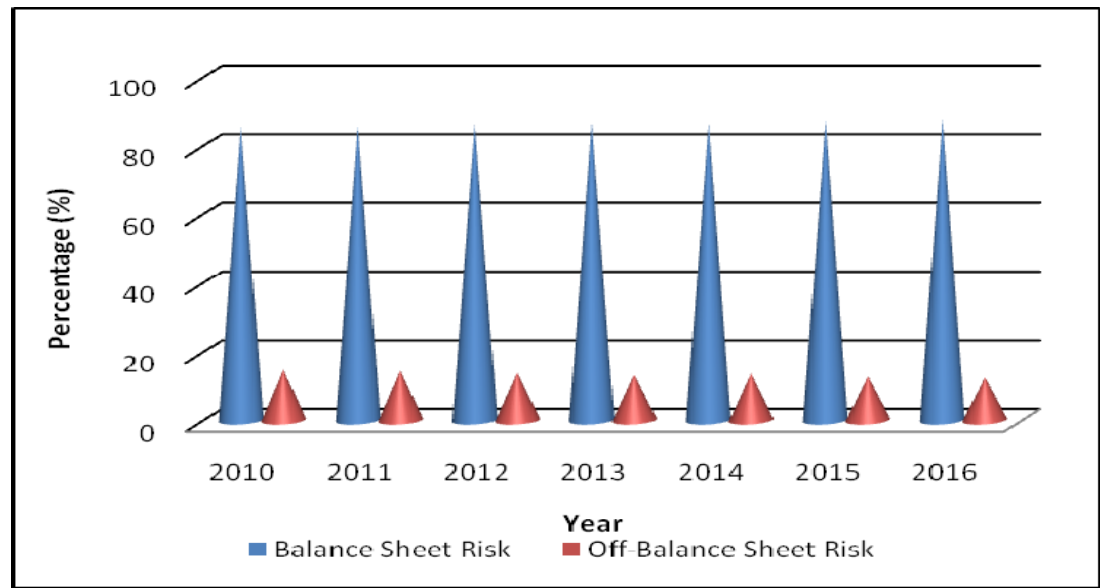

Chart 3. Banking sector credit risk structure under Basel III

\subsubsection{The share of Credit Risk}

The chart 6.4 below showed the share in industry credit risk of top 5 and 10 banks. In fact, it covers the area of risk concentration which is the most significant area in financial management. In evaluating Top 5 banks from the year 2010 to 2016, it was found that the credit risk concentration was very high which were $28.00 \%$ in $2010 ; 26.90 \%$ in $2011 ; 27.50 \%$ in $2012 ; 25.5 \%$ in $2013 ; 25.5 \%$ in $2014 ; 24.4 \%$ in 2015 ; and $23.6 \%$ in 2016 , although the trend was decreasing. It indicates that approximately $26 \%$ of credit risk holds by the top 5 banks. However, in the case of Top 10 banks, the result was very disappointing. It is notable that the credit risk share increased in the year 2011 from 2010 by $5 \%$ and the average trend of risk occupied by top 10 banks was $45 \%$. It revealed that the remaining forty-seven (47) banks only hold $55 \%$ credit risk in the industry. This is the red signal for the industry that the risk concentration is very high and can affect negatively in the economy.

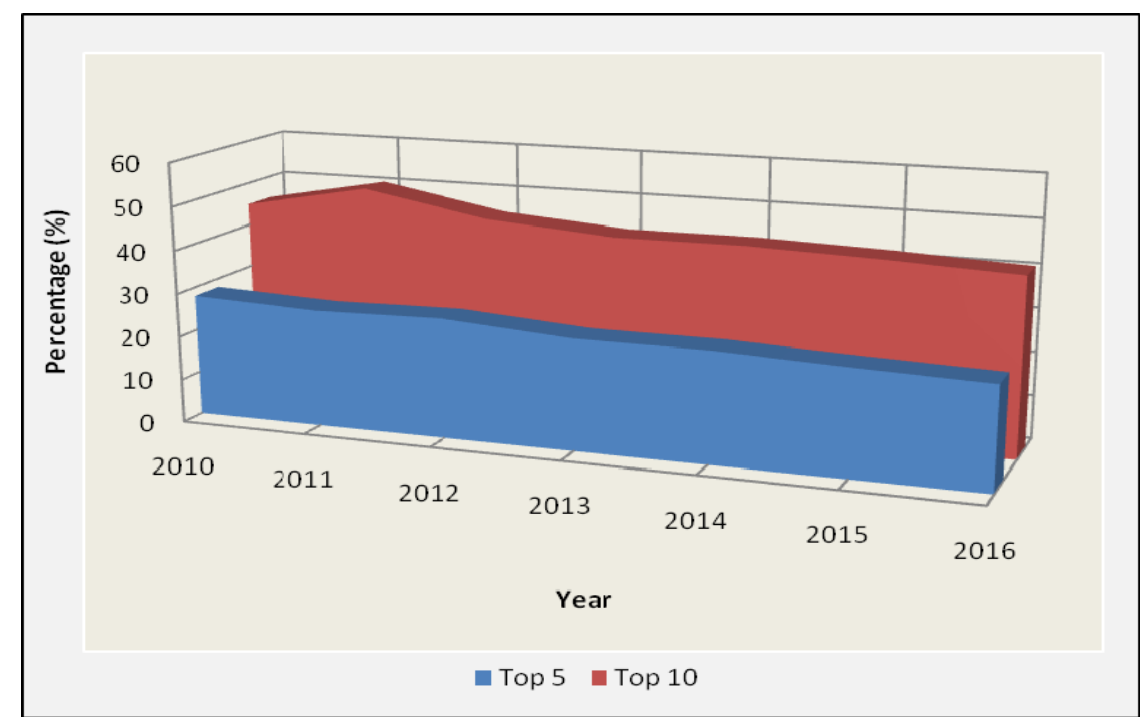

Chart 4. Share in industry credit risk (\%)

\subsubsection{Share in industry overall risk}

According to the framework, the overall risk comprises into credit risk, market risk, and 


\section{Macrothink}

operational risk. The study found that among all the categories, credit risk occupied the major or significant portion of the overall risk. In the case of Top 5 banks, it is found that in 2013 the overall risk share slightly increased which was $24.6 \%$. The average trend was approximately $23 \%$. Again, in the case of Top 10 banks, the share in overall risk has a decreasing trend after the year of 2013. From the year 2010 to 2016, the highest position was in 2013 which showed $41.4 \%$. The average trend was 38\% which indicates that top 10 banks captured the major portion of risk as the remaining 47 banks hold only $52 \%$ of risk. The risk concentration was very high both in the case of credit risk and overall risk. The regulatory authority should take preventive measures to disseminate the big chunk of risk over the banks. Risk dissemination and risk reduction are the only solutions to handle the market without intervention. The open market theory may be distorted by the intervention of the regulators, but there is no way to tackle the situation.

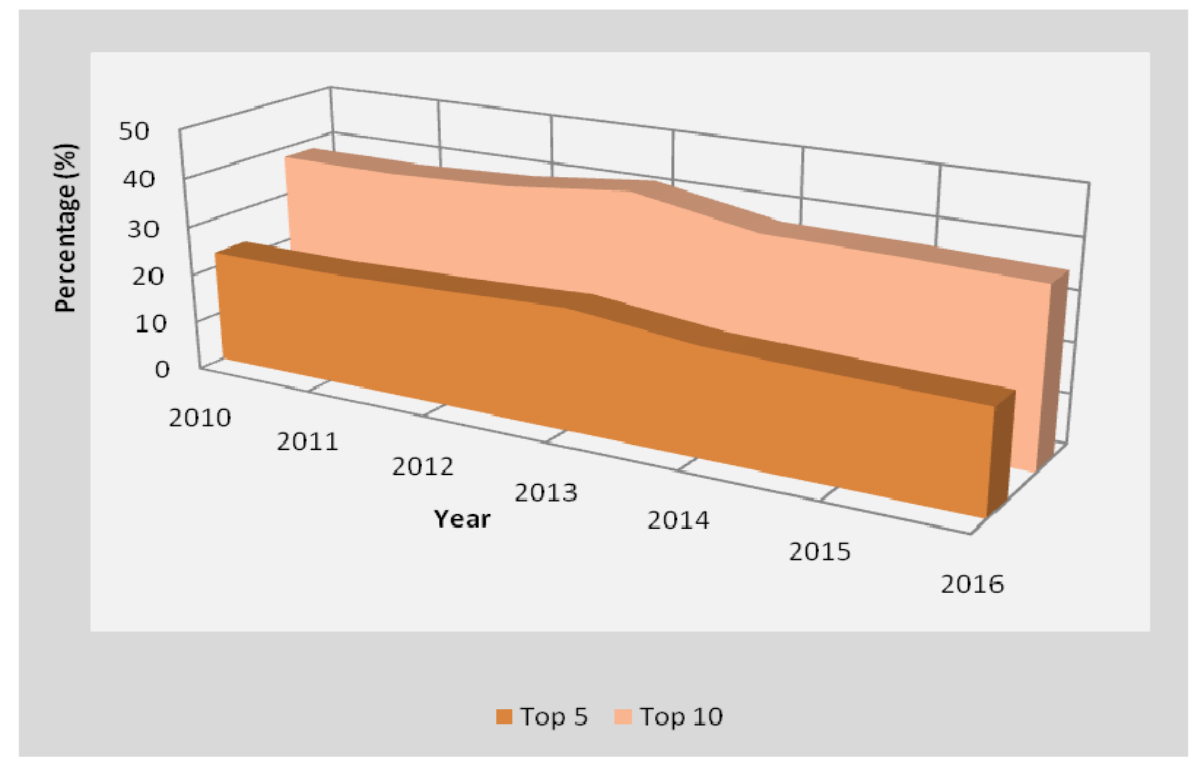

Chart 5. Share in overall industry risk (\%)

\subsubsection{Group allotment of share in credit risk}

The group-wise distribution of credit risk is presented in the Chart below. It is found that Group 1 (consists of twenty-two (22) Private commercial banks) kept the maximum portion of credit risk which is more than 50\%. However, the lower percentage of credit risk occupied by Group 4 (Foreign commercial banks) and Group 5 (Fourth generation private commercial banks) which is approximately $8 \%$, the accumulation of both groups. But Group 2 and Group 3 together consumed on an average $42 \%$ of the risk. The result is that 22 banks consume on an average $50 \%$ of risk where $42 \%$ of risk consumed by 17 banks and the remaining $8 \%$ risk for 18 banks. The most vulnerable position is for the Group 2 (State-owned and Private commercial banks under special attention) and Group 3 (Full-fledged Islamic banks). 


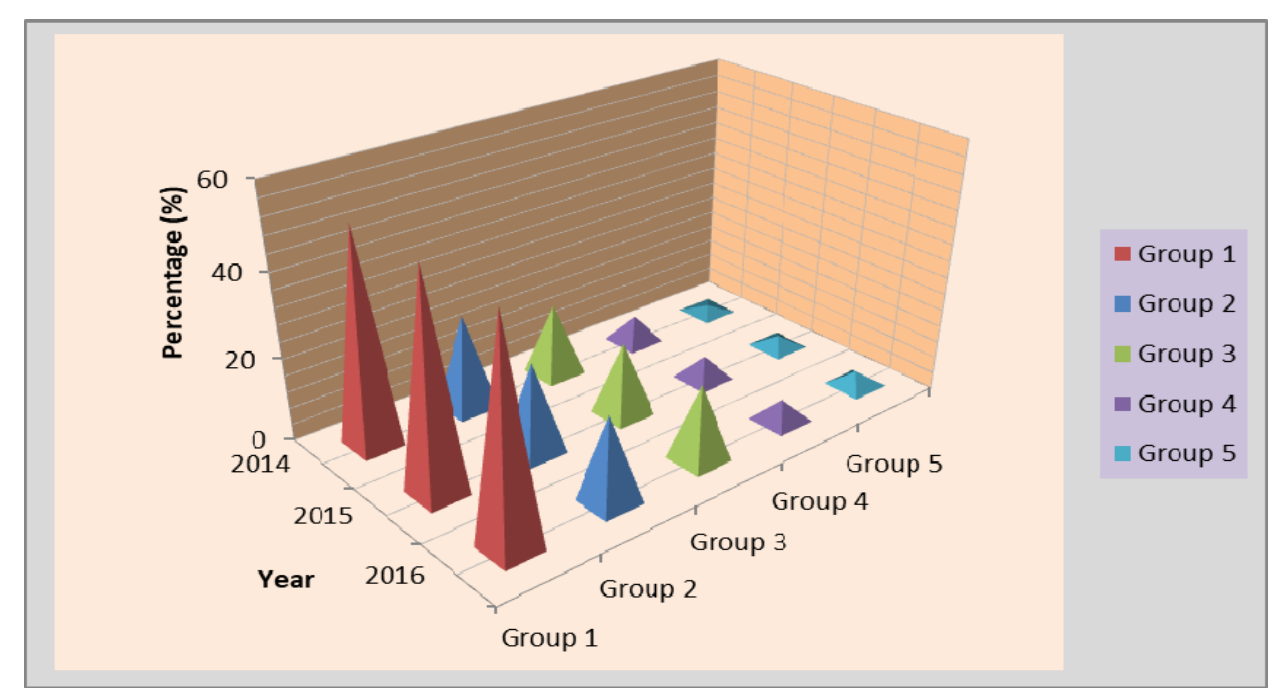

Chart 6. Share in industry credit risk (\%)

\subsubsection{Group allotment of share in the overall risk}

The group-wise allocation of shares in overall risk is depictedin the Chart below. It is found that twenty-two (22) private commercial banks which are leveled by Group 1 hold the maximum portion of risk which is $45 \%$ on an average. The lowest portionholds by foreign commercial banks (Group 4) and Fourth generation private commercial banks (Group 5), all together have a mean value of $7 \%$. Therefore, the remaining $48 \%$ of average risk is consumed by 17 banks that are the accumulation of Group 2 and Group 3 banks. From the above discussion, the study identified that the state-owned banks, as well as full-fledged Islamic banks, are responsible in taking the extravagantrisk since they have the market share of $30.60 \%$ in the industry level. The study conducted by Sarker and Nahar (2017) identified that state-owned banks are mostly working as an agent of the government and busy with the implementation of political agendas as the governance system are not strong enough that can follow the contractionary policy. On the other hand, the Islamic banks are operated with religious belief but not efficient in all respect. The rules and regulation should be changed and make uniform standards for all types of banks otherwise the controlling power of the regulator will be fall under pressure. 


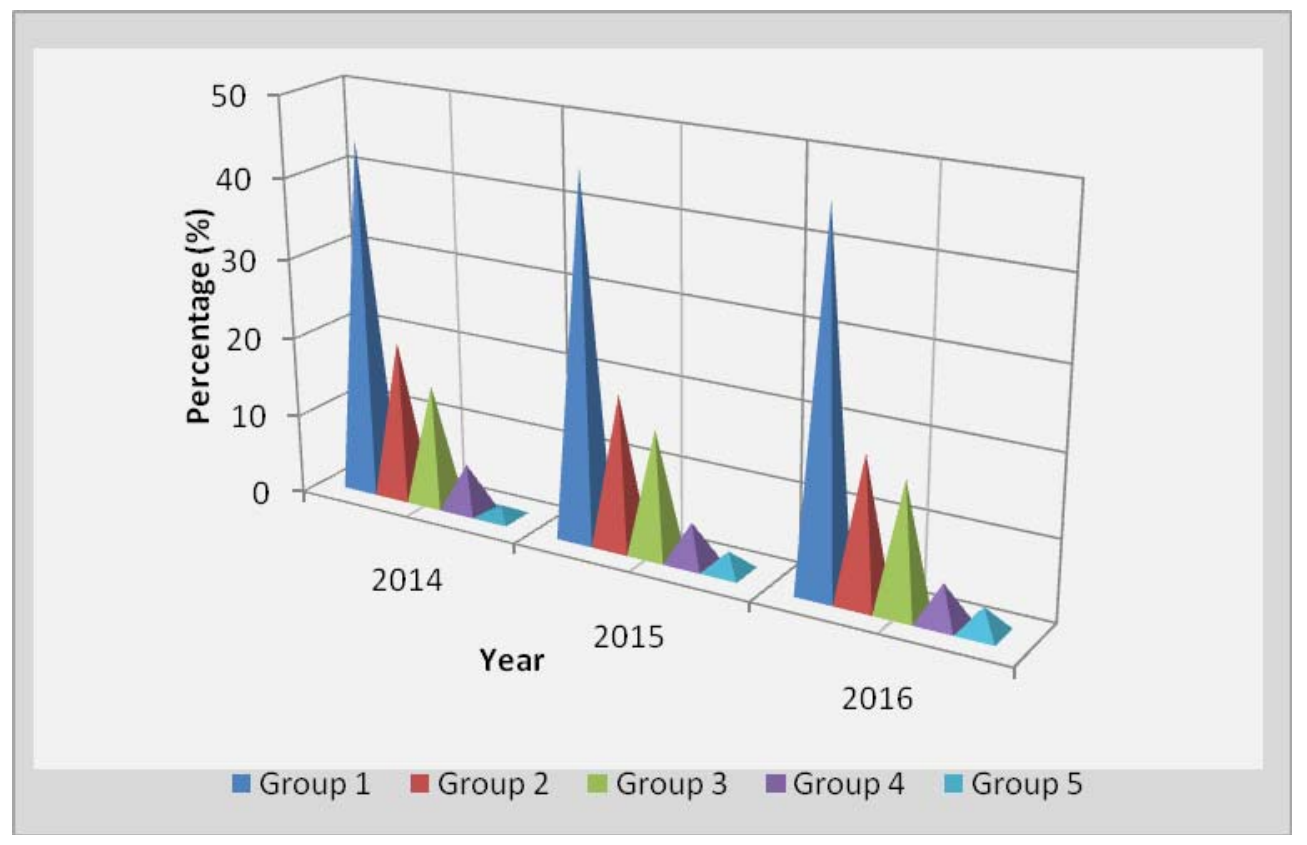

Chart 7. Share in overall industry risk (\%)

\subsubsection{Market Risk disclosures under Basel III norms}

The nature of market risk is characterized by the loss of on- and off-balance sheet position due to the shift in market price. The adverse shift in market price depends on the interest rate (Note 5), foreign exchange rate (Note 6), equity price(Note 7), credit spreads (Note 8) and commodity prices (Note 9). The sources of market risk are explained in Basel III where the main attribution concerned with interest rate related instruments and equities and also with currency fluctuation in the global economy. The Chart below shows the trend of market risk under Basel III from the year 2010 to 2016. The study found that market risk has downward trend from the year 2010 to 2012 which were $7.0 \%$ in $2010,6.2 \%$ in 2011 and $5.2 \%$ in 2012 but in 2013 it had an upward trend which was 6\%. Later on, from the year 2013 to 2016, there was a decreasing trend which was $5.3 \%$ in $2014,4.5 \%$ in 2015 and $3.8 \%$ in 2016 . The turbulence in the security market during the year 2011, the reaction negatively affects the market sentiment which did not work enough to in recovery and volatility in turnover in the year 2013. It is also found that the moderate level of volatility in the turnover attributed to the market risk for banks in the year 2013. The market risk is usually quantified grounded on the volatility of bank earnings and the economic value of its capital. Except in the year 2013, the overall trend of market risk showed a very strategic decline through the portion of the risk is small regarding overall risk. 


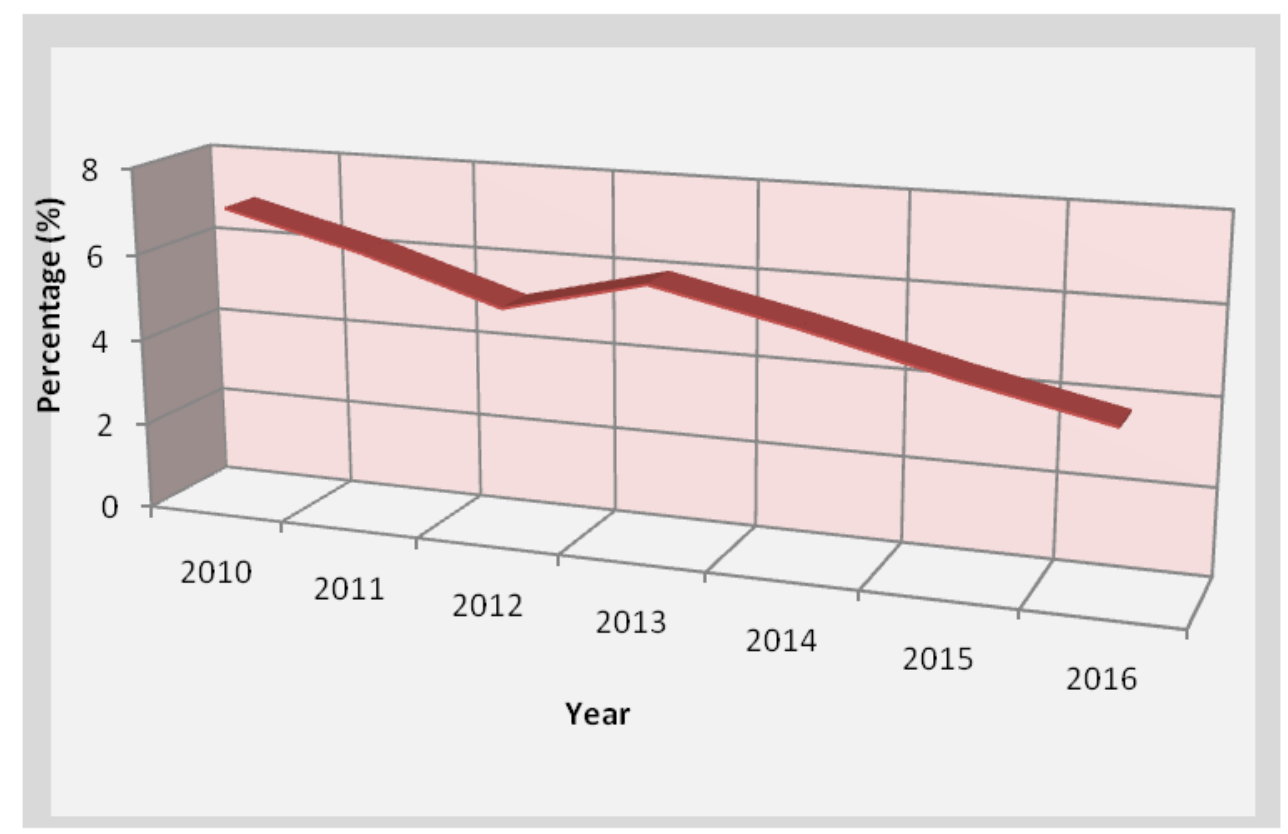

Chart 8. Market risk under Basel III reported from the Year 2010 to 2016

\subsubsection{The trend of Market Risk in comparison with Other Risk}

In comparisonto market risk with another risk, the study found that the portion of the market risk is the insignificant portion of the total risk. In fact, the highest portion occupied by the credit risk and led by the non-performing loans. However, the market risk exposures are structured and have lower involvement of internal factors that are generated in the marketplace. The study found that the market risk has downward trends whereas the other risk has an upward trend from the year 2010 to 2016 . The value of other risk as a percentage of total risk was $93.0 \%$ in $2010 ; 93.8 \%$ in $2011 ; 94.8 \%$ in $2012 ; 94.0 \%$ in $2013 ; 94.7 \%$ in 2014; $95.5 \%$ in 2015 ; and $96.2 \%$ in 2016 . Therefore the remaining portion held for market risk is insignificant in consideration of total risk exposure. 


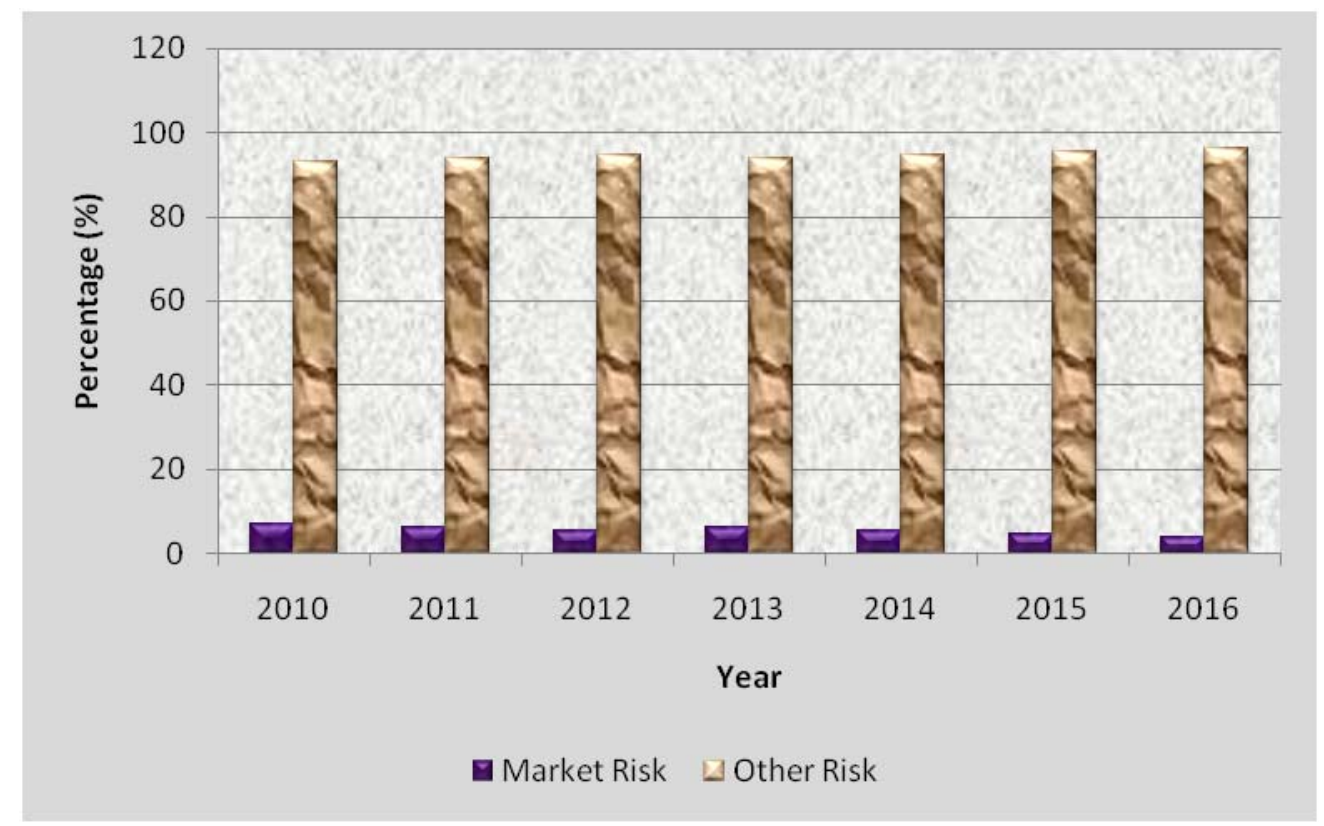

Chart 9. Market Risk in comparison with Other Risk from the Year 2010 to 2016

\subsubsection{The component of Market Risk and its trend}

The market risk is largely affected by its broad-headed components which are equity risk, interest rate risk and foreign exchange position risk. Among these aspects, equity risk occupied the maximum portion whereas the interest rate risk and foreign exchange position risk jointly take the position below equity risk. The trend curve showed that equity risk gradually decreased from the year 2010 of $62.7 \%$ to 2011 of $52.1 \%$ whereas interest rate risk also has a downward trend which was $27.8 \%$ in 2010 and $21.1 \%$ in 2011 but the foreign exchange position risk sharply increased in 2011 which was $6.7 \%$ more than the previous year. In the year 2011 to 2012, the case was reversed for equity risk and foreign exchange position risk but similar to the case of interest rate risk. From the year 2012, it is found that the equity price risk are gradually decreased with $63.4 \%$ in $2012 ; 56.6 \%$ in $2013 ; 49.5 \%$ in $2014 ; 48.7 \%$ in 2015 ; and $48.7 \%$ in 2016 whereas interest rate risk has a growing trends with $20.2 \%$ in $2012 ; 26.1 \%$ in $2013 ; 32.2 \%$ in $2014 ; 32.7 \%$ in 2015 and $32.7 \%$ in 2016 . In the case of foreign exchange position risk, it is found that there was a slightly increasing trend from the year 2012 to 2016 with value $16.4 \%$ to $18.5 \%$. To sum up, it is revealed that equity price risk constituted the highest position of market risk in the stated time horizon and interest rate risk also have the same tendency but flowed below the equity price risk. 


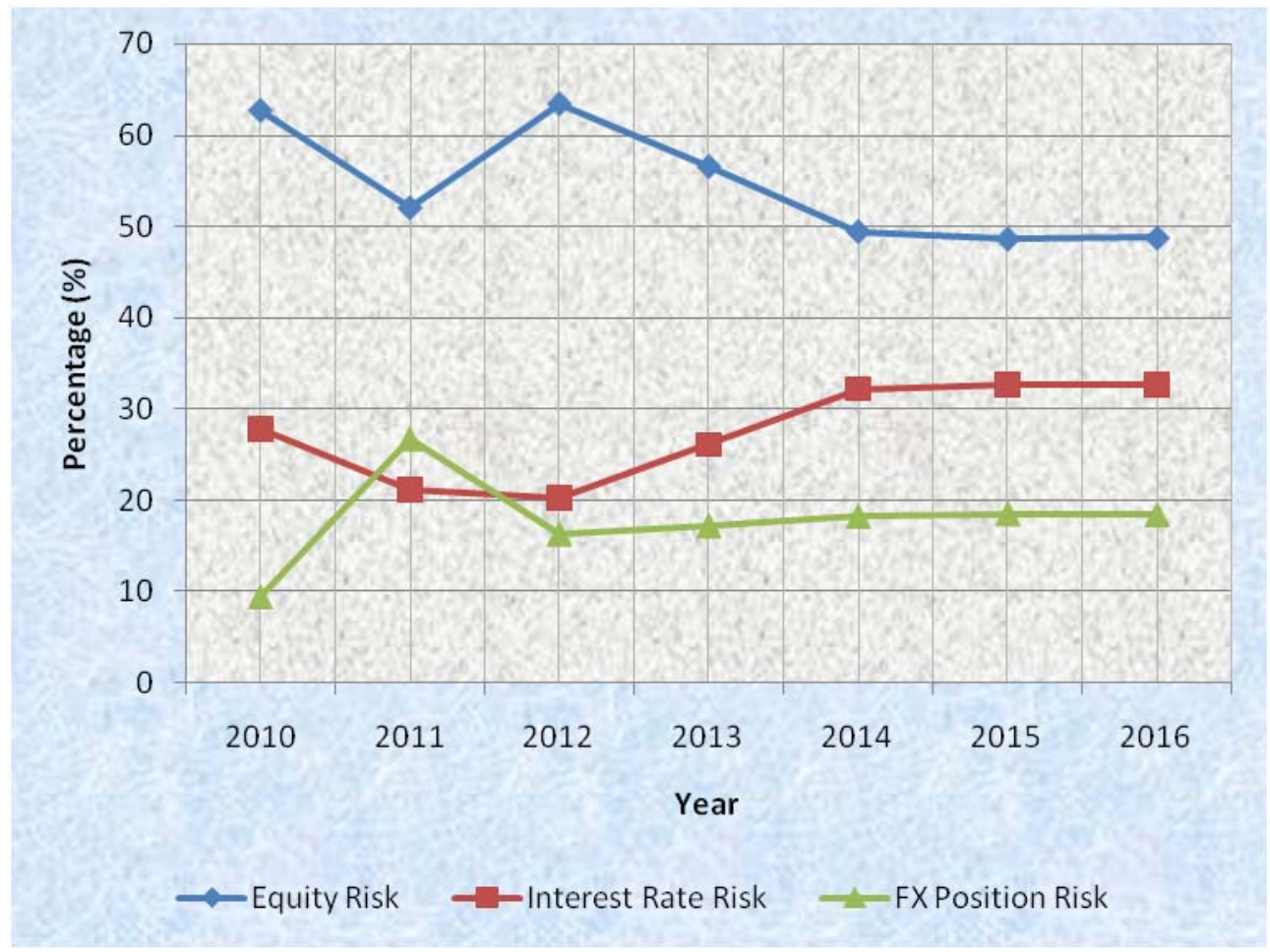

Chart 10. Market Risk components from the Year 2010 to 2016

\subsubsection{3: Group wise share of Market risk}

The Table below showed the group-wiseshare of market risk focusing on interest rate risk, equity price risk, and exchange rate risk. It is found that Group 1 ( 22 Private commercial banks) and Group 2 ( 10 State-owned and Private commercial banks under special attention) are aggregately occupied $90.2 \%$ of interest rate risk in the segment of market risk in 2016 whereas both of the Groups exposed $86.6 \%$ of equity price risk. These statistics found that local banks both state-owned and private commercial are engaged with interest rate related instruments and responsible for the stock market investment in the baking system. Moreover, these Groups are possessed combined $62.3 \%$ of exchange rate risk in 2016 but in the case of Group 3 (7 Full-fledged Islamic banks) is unexpectedly higher consumer of exchange rate risk which is $27 \%$. It is noticeable that, Group 4 (9 Foreign commercial banks) and Group 5 (9 Fourth Generation private commercial banks) are less exposed to market risk in the banking industry. In the year 2015, it is found that Group 1 and Group 2 were combinedly occupied by $88.1 \%$ of interest rate risk and $88.9 \%$ of equity price risk. Group 2 alone exposed more share in exchange rate risk which was $37.5 \%$ in the year of 2015. In all cases, Group 4 and Group 5 are less exposed to market risk in both of the year 2015 and 2016 as well. The question may be raised that why Group 3 banks have zero (0) share of interest rate risk in both of the years. The answer comes from the basic principle of Group 3 (Full-fledged Islamic banks) banks that they are initiatedby religious belief where interest is totally prohibited and banned in ideological thoughts. They are dealing with money and distribute profits but ignore the interest. So, their reporting system omits the interest related items from the statements. 


\section{Macrothink}

Table 5. Group wise dissection of Market Risk in the Banking System

\begin{tabular}{llccc}
\hline Year & $\begin{array}{l}\text { Bank } \\
\text { Group }\end{array}$ & $\begin{array}{c}\text { Share in Industry } \\
\text { Interest Rate Risk }\end{array}$ & $\begin{array}{c}\text { Share in Industry } \\
\text { Equity Price Risk }\end{array}$ & $\begin{array}{c}\text { Share in Industry } \\
\text { Exchange Rate Risk }\end{array}$ \\
\hline \multirow{4}{*}{$\mathbf{2 0 1 6}$} & Group 1 & 32.8 & 53.1 & 36.6 \\
& Group 2 & 57.4 & 33.3 & 25.7 \\
& Group 3 & 0.0 & 12.2 & 27.0 \\
& Group 4 & 2.4 & 0.0 & 9.0 \\
& Group 5 & 7.4 & 1.4 & 1.7 \\
& Total & $\mathbf{1 0 0}$ & $\mathbf{1 0 0}$ & $\mathbf{1 0 0}$ \\
& Group 1 & 47.7 & 53.5 & 34.1 \\
& Group 2 & 40.4 & 35.4 & 37.5 \\
$\mathbf{2 0 1 5}$ & Group 3 & 0.0 & 9.7 & 22.8 \\
& Group 4 & 5.8 & 0.0 & 2.8 \\
& Group 5 & 6.1 & 1.4 & 2.8 \\
& Total & $\mathbf{1 0 0}$ & $\mathbf{1 0 0}$ & $\mathbf{1 0 0}$ \\
\hline
\end{tabular}

\subsubsection{Market risk concentration}

The market risk concentration is explained by the top 5, and top 10 banks risk exposure in the banking industry. It is very important for the economy that how many are the player or big giants who arrange the market and keep the control. If the lower position of banks exposed higher risk, then it will be a threat to the industry. The best thing is the allocation of risk over the participants in a rational way.

In the case of Interest Rate Risk (IRR), it is found that Top 5 banks were captured $46 \%$ in $2010 ; 43.4 \%$ in $2011 ; 45.6 \%$ in $2012 ; 67.7 \%$ in $2013 ; 46.7 \%$ in $2014 ; 53.2 \%$ in 2015 ; and $67 \%$ in 2016 . It indicates that top 5 banks expose approximately $53 \%$ of the interest rate risk. Only $47 \%$ IRR is consumed by remaining 52 banks in the baking industry of Bangladesh. The case is severe for those five (5) banks that experienced higher market risk over the period. The Top 5 banks in this regard are three (3) State-owned commercial banks and two (2) private commercial banks. 


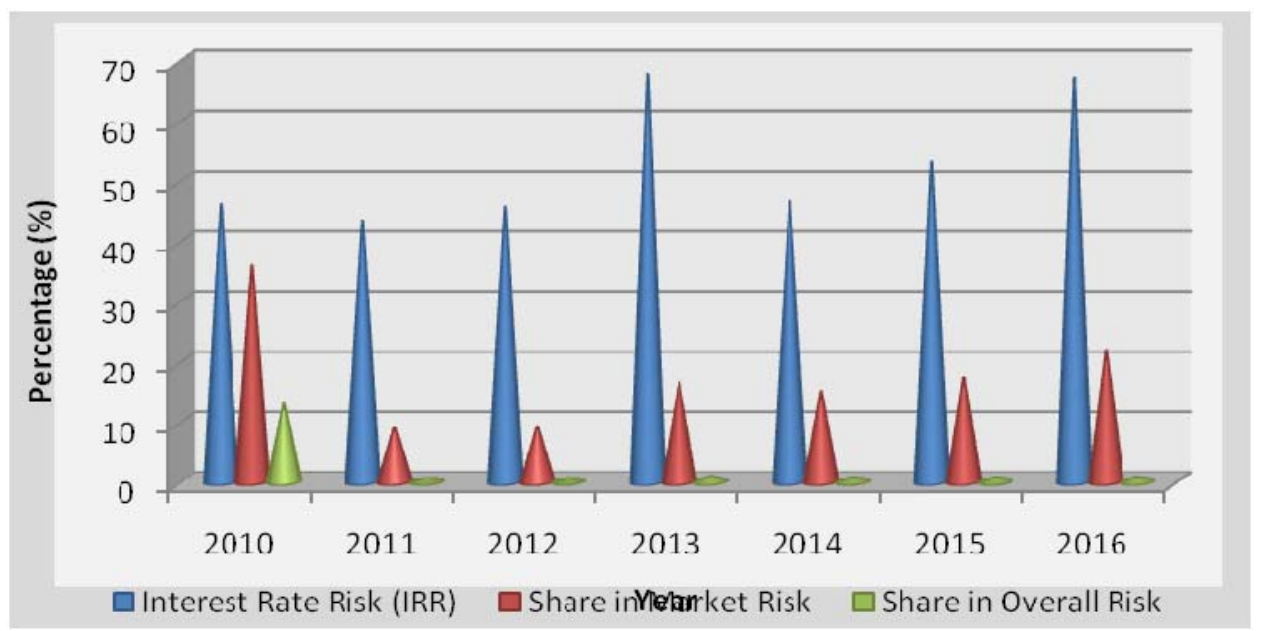

Chart 11. Interest Rate Risk exposed by Top 5 banks

In the case of To 10 banks, it is found that, the IRR has increasing trend that was in 2010; $67.6 \%$ in $2011 ; 72 \%$ in $2012 ; 94.9 \%$ in $2013 ; 68.8 \%$ in $2014 ; 72.1 \%$ in 2015 ; and $83.7 \%$ in 2016. The average value is $75.44 \%$ indicates that only ten (10) banks consume amaximum portion of interest rate risk (IRR) remaining $24.56 \%$ held for forty-seven (47) banks. Therefore the regulators should evaluate the consequences and take immediate action for the disposal of extravagant risk.

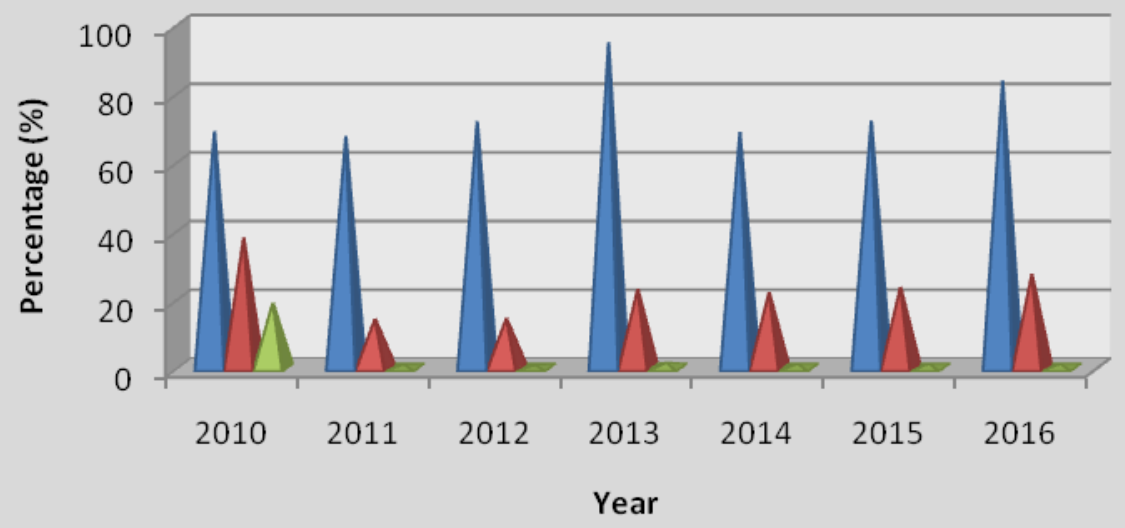

$\square$ Interest Rate Risk (IRR) $\quad \square$ Share in Market Risk $\quad \square$ Share in Overall Risk

Chart 12. Interest Rate Risk exposed by Top 10 banks

In the case of Exchange Rate Risk (ERR), Top 5 banks holdon an average $52.9 \%$ risk and remaining $47.1 \%$ held for 52 banks. The risk concentration for the top 5 banks is very high. Among the years, the highest risk was exposed in 2011 which was $71.1 \%$. It also indicates that the top 10 banks hold major portion of interest rate risk (IRR) which is detrimental to the economic stabilization. 


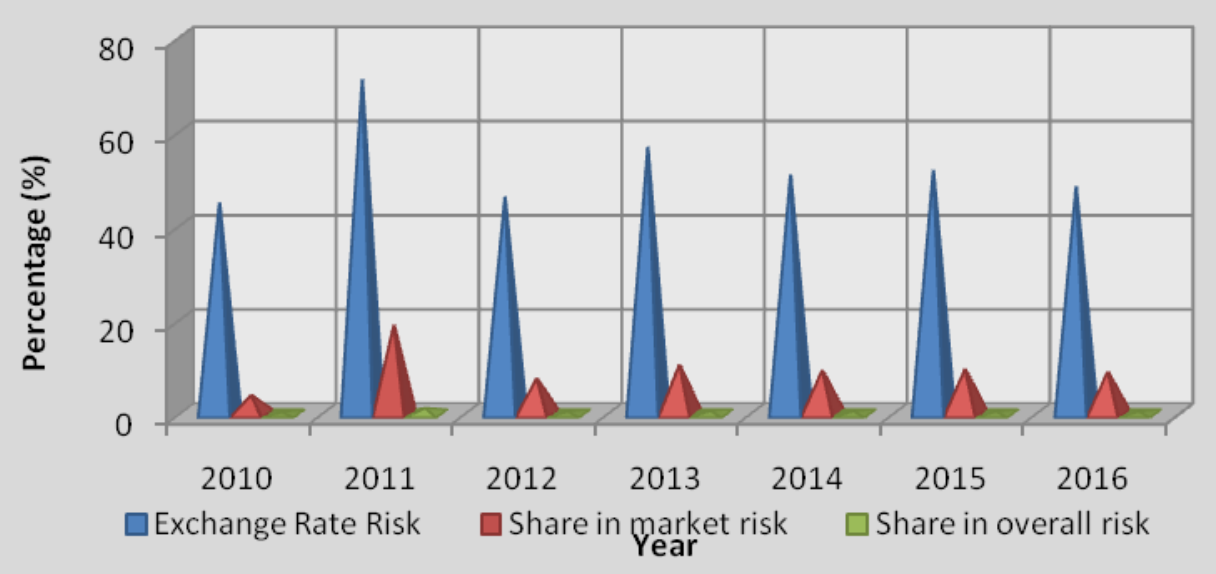

Chart 13. Exchange Rate Risk exposed by Top 5 banks

The chart below showed the exchange rate risk exposure of top10 banks in the banking sector of Bangladesh. It was found that the trends of ERR was $62.0 \%$ in $2010 ; 81.8 \%$ in 2011 ; $67.8 \%$ in $2012 ; 72.1 \%$ in $2013 ; 69.4 \%$ in $2014 ; 67.5 \%$ in 2015 ; and $64.6 \%$ in 2016 with average value of $69.31 \%$. The study revealed that remaining $30.69 \%$ of exchange rate risk (ERR) held for 47 banks. The risk concentration is very high for both top 5 and top 10 banks.

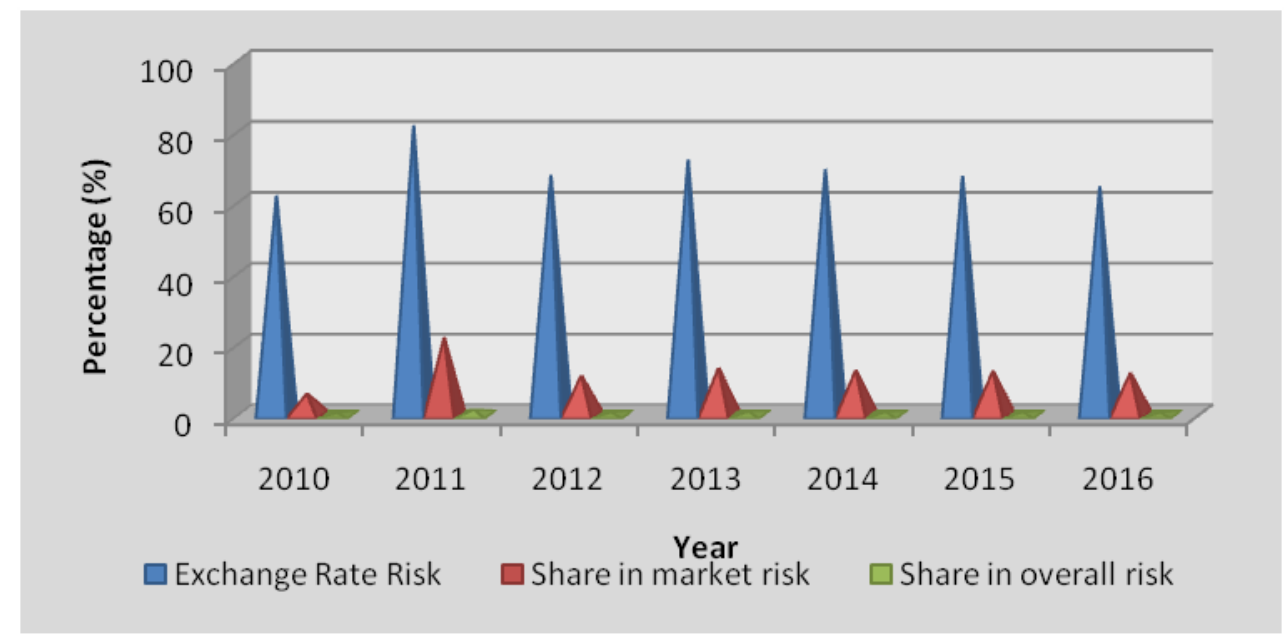

Chart 14. Exchange Rate Risk exposed by Top 10 banks

In the case of Equity Price Risk (EPR), Top 5 banks showed that they exposed thehighest risk in 2010 which was $47 \%$ but later on from the year 2011 to 2013, there was a gradual increase of EPR with the value of $37.8 \%, 45.3 \%$, and $48.6 \%$ successively. After the year of 2013 , the trend of ERR slightly decreased. In the year of 2016, the ERR stood $38.1 \%$ which was the lowest among the selected periods. It also revealed that $43.29 \%$ of average risk was consumed by the top 5 banks from the year 2010 to 2016 . 


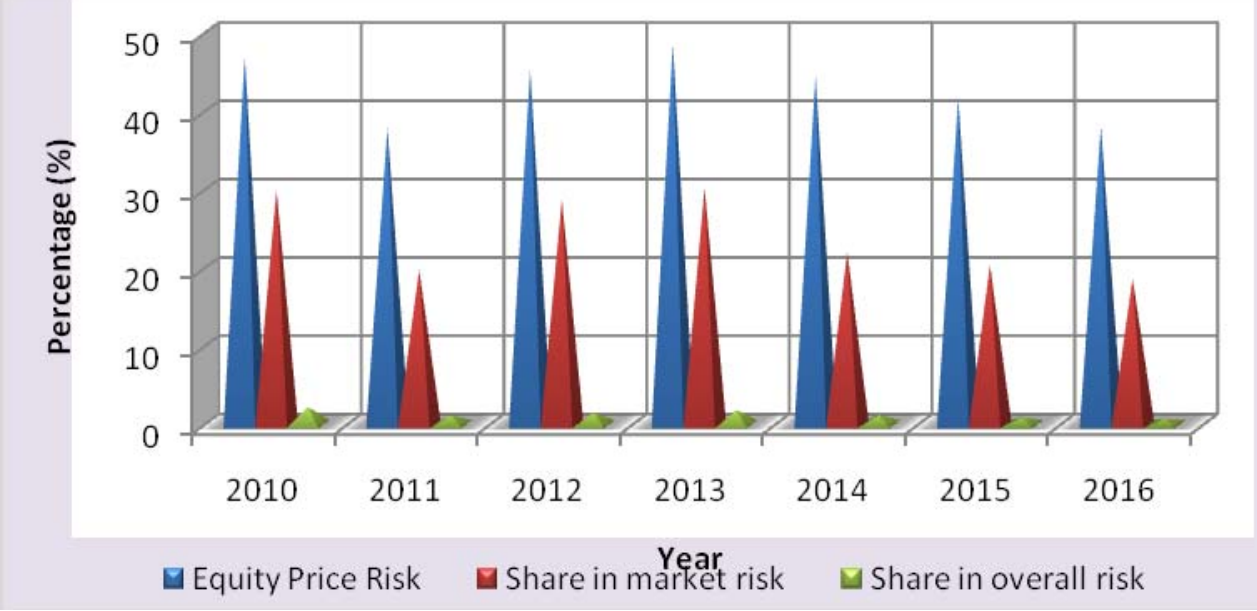

Chart 15. Equity Price Risk exposed by Top 5 banks

However, the concentration of top 10 banks showed that equity price risk (EPR) was $72 \%$ in $2010 ; 50.9 \%$ in $2011 ; 69.6 \%$ in $2012 ; 71.0 \%$ in $2013 ; 68.6 \%$ in $2014 ; 67.3 \%$ in 2015 ; and $59.5 \%$ in 2016 . The average value was $65.56 \%$ which indicates that the major portion of EPR exposed by to 10 banks.

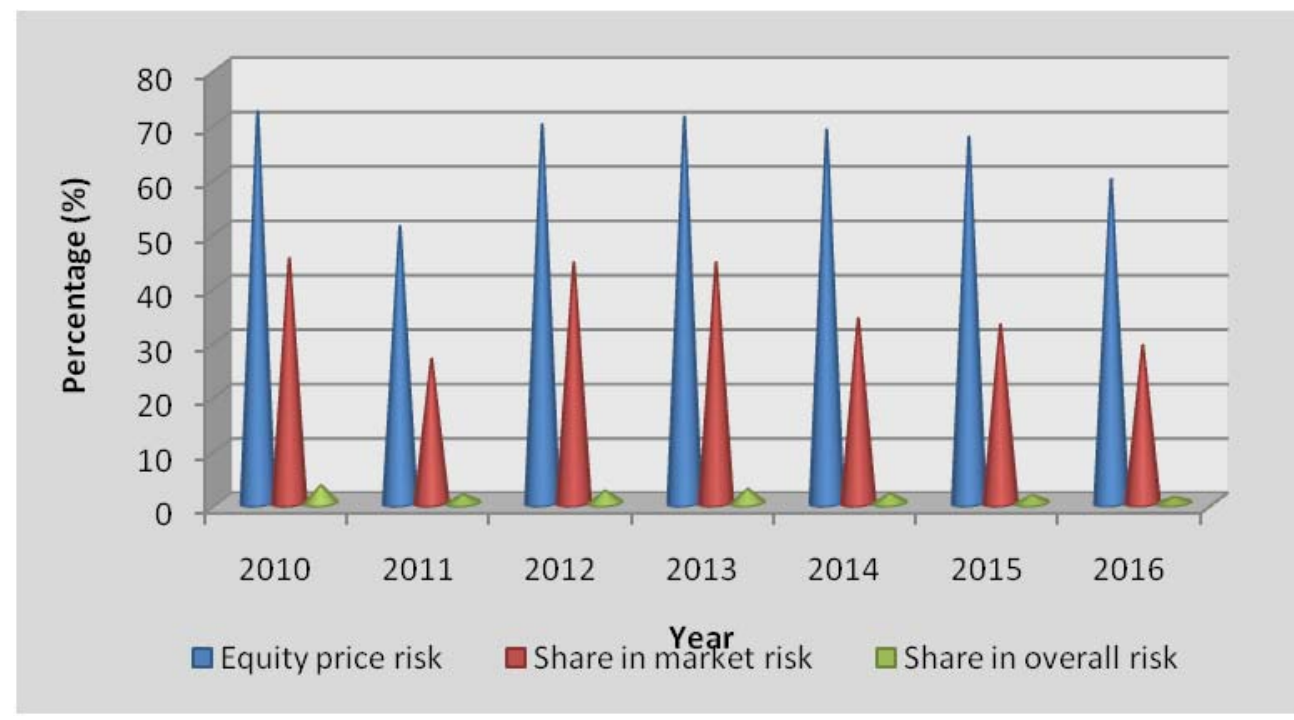

Chart 16. Equity Price Risk exposed by Top 10 banks

\subsubsection{Operational Risk disclosures}

The operational risk arises from the financial losses and causes by the disruption of the internal control system and corporate governance. The causes may be initiated using human error, inadequate internal control system, interrupted technical system, intentional misstatement or any sought of adverse situations.

In the context of present-day banking and financial sector irregularities, balance development and high growth are not possible. That is why radical reform in this sector is the time demand. While there are many questions about the list of top 100 loan defaulters, this type of listing 
can encourage banks to get default loans and encourage borrowers not to be defaulted. Most of the top 100 loan defaulters have been published by the public bank's customers. Due to irregularities and corruption of the years to years, lack of good governance, the central bank's control has become less and more difficult for these banks. There are some institutions in debt defaulters who have defaulters in more than one government bank. Some companies, government banks, as well as private banks, have defaulters. But many other institutions are out of the list of debt restructures and reconstructions and the court writings. Also, banks have excluded many institutions and excluded the accounts from the accounts. If these are considered then the picture of the defaulted loan will be even worse.

In operational risk, the entity is fall in the crisis due to their loose governance policy, improper monitoring system and weak internal control policy.

\subsubsection{Operational Risk concentration}

The chart below showed that to 5 banks is exposed less than $30 \%$ of risk from the year 2010 to 2016. It is noticeable that the highest operational risk was in the year of 2011 and lowest stood in 2013. However, the share of operational risk in overall industry risk was negligible from 2010 to 2016 at the value of $2.3 \%, 2.6 \%, 2.4 \%, 2.2 \%, 2.5 \%, 2.6 \%$, and $2.5 \%$ consecutive from the beginning.

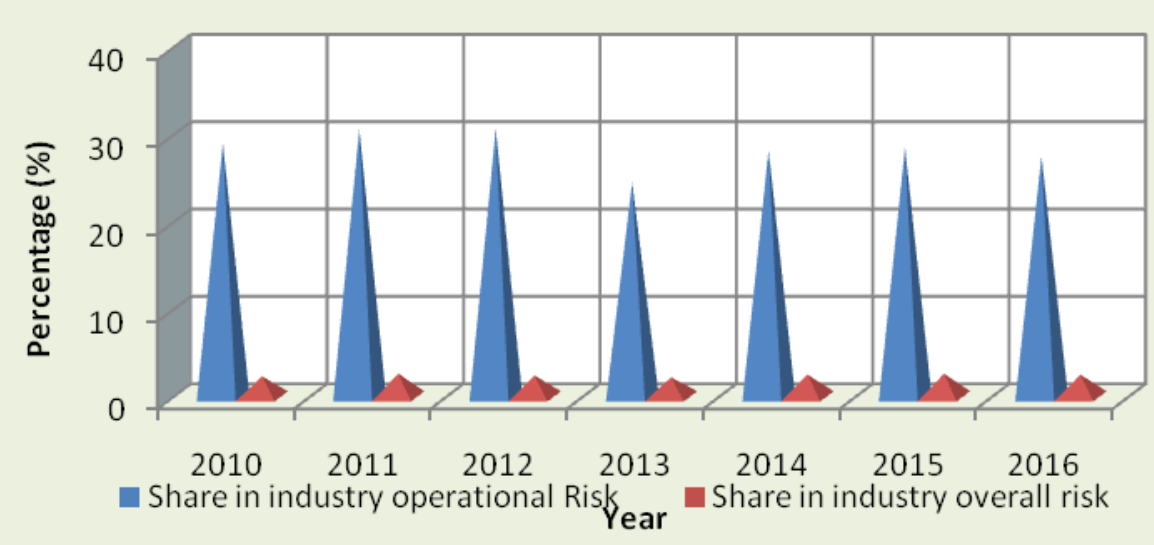

Chart 17. Operational Risk exposed by Top 5 banks

In the case of Top 10 banks, the study found that operational risk exposed $46.0 \%$ in 2010 ; $48.2 \%$ in $2011 ; 47.7 \%$ in $2012 ; 35.1 \%$ in $2013 ; 45.9 \%$ in $2014 ; 45.4 \%$ in 2015 ; and finally $44.4 \%$ in 2016 . That indicates that top 10 banks occupied more than $40 \%$ of operational risk whereas $60 \%$ held for 47 banks. Therefore, in all respects, risk concentration for top 5 or top 10 banks was higher in position. The risk concentration symptom is not good for the developing country like Bangladesh. 


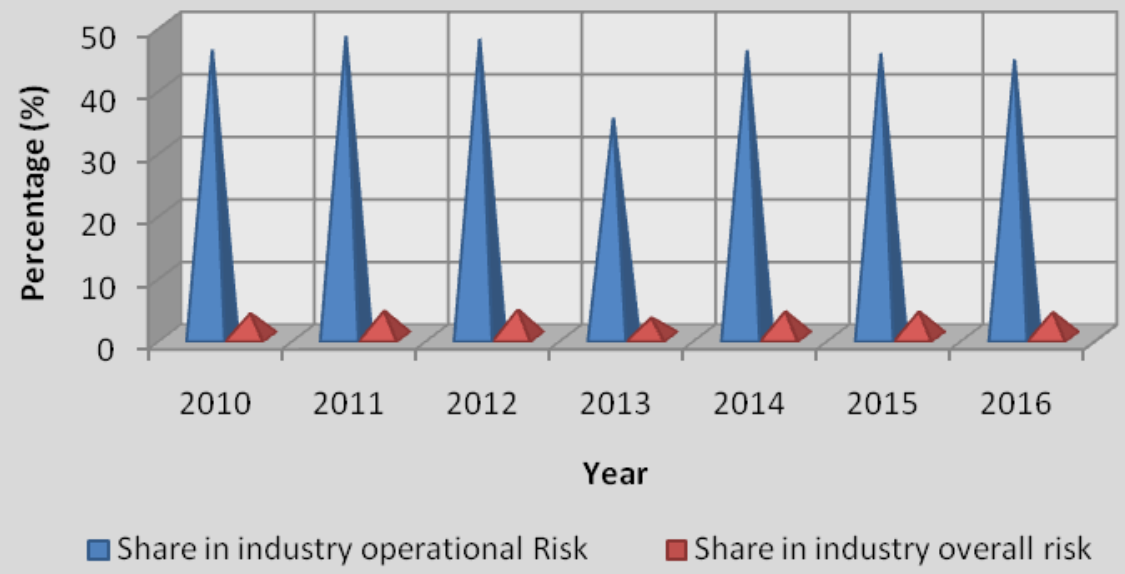

Chart 18. Operational Risk exposed by Top 10 banks

\subsubsection{Group-wise Dissection of Operational Risk}

The Table below found that Group 1 and Group 2 banks aggregately exposed $73.1 \%$ share of industry operational risk in 2016 and also in the same trend in the prior periods. The lowest risk exposed by the Group 5 banks where they have $1.0 \%$ in $2014,1.5 \%$ in 2015 , and $2.3 \%$ in 2016 as a share of operational risk. Again, in the case of overall risk, it is found that Group 1 banks have more risk in comparison with other groups. The lowest risk held for Group 4 in the year of 2014, 2015, and 2016 as well.

Table 6. Group-wise Dissection of Operational Risk in the Banking System

\begin{tabular}{lccc|ccc}
\hline & \multicolumn{3}{c}{ Share in Operational industry Risk } & \multicolumn{3}{c}{ Percentage (\%) } \\
\hline & Year 2014 & Year2015 & Year 2016 & Year2014 & Year2015 & Year2016 \\
\hline Group 1 & 50.7 & 50.3 & 50.9 & 4.6 & 4.5 & 4.6 \\
Group 2 & 22.9 & 22.7 & 22.2 & 2.1 & 2.1 & 2 \\
Group 3 & 14.8 & 14.8 & 14.9 & 1.3 & 1.3 & 1.3 \\
Group 4 & 10.6 & 10.7 & 9.7 & 0.9 & 1.0 & 0.9 \\
Group 5 & 1.0 & 1.5 & 2.3 & 0.1 & 0.1 & 0.2 \\
\hline
\end{tabular}

\section{Conclusions}

The Finance Ministry, Bangladesh Bank, Parliamentary Committees have provided guidelines to prevent the defaulting loan. The governing board of the state-owned commercial banks, the management authority and the finance ministry and the instructions of the Bangladesh Bank, according to the advice; are taking steps to upgrade the defaulting loan of their banks. Organizing regular meetings, monitoring the results of the workflow is taken at the field level. The branches have jumped with the supremacy of defaulting money. The absence of defaulting loan is a good sign of the banking sector. Such images are shown due to credit without scrutiny. In this way, the discipline of the bank will be broken. Moreover, there will be a negative impact on interest rates as well as on investments. Political influences for 
granting credit by the chairman, director and Managing Directors (MDs) of the bank - is the main reason behind the inadequacies of the credit. This is the high time to buildup an awareness program to stop the loan path without checking. Otherwise, the amount of bad credit can be increased.

Bangladesh Securities and Exchange Commission (BSEC) has given permission the following eight (8) credit rating agencies along with Moody's Investors Service, Standard \& Poor's Rating Service, and Fitch Ratings so that the real scenario of the baking position can be imaginable.

Table 7. Commencement of credit rating agencies in Bangladesh

\begin{tabular}{llll}
\hline Sl. No. & Rating Agency & Year of Inception & Subsidiary/Technical partner of \\
\hline $\mathbf{1}$ & Credit Rating Information and Services Ltd. (CRISL) & 1995 & Rating Agency Malaysia Berhad \\
$\mathbf{2}$ & Credit Rating Agency of Bangladesh Ltd. (CRAB) & 2003 & ICRA Limited of India \\
$\mathbf{3}$ & Emerging Credit Rating Ltd. (ECRL) & 2009 & Malaysian Rating Corporation Berhad \\
$\mathbf{4}$ & National Credit Rating Ltd. (NCRL) & 2010 & The Pakistan Credit Rating Agency Ltd. \\
$\mathbf{5}$ & ARGUS Credit Rating Services Ltd. & 2011 & DP Information Group, Singapore \\
$\mathbf{6}$ & WASO Credit Rating Company (BD) Ltd. & 2012 & Financial Intelligence Services Ltd. \\
$\mathbf{7}$ & Alpha Credit Rating Ltd. & 2012 & Istanbul International Rating Services Inc. \\
\hline
\end{tabular}

Source: Fiscal Stability Report (2015), Fiscal Stability Department, Bangladesh Bank

\section{References}

Abraham, S. and Cox, P. (2007). Analyzing the determinants of a narrative risk information in UK FTSE 100 annual reports. British Accounting Review, 39(3), 227-248. https://doi.org/10.1016/j.bar.2007.06.002

Al-Tamimi, H.A.H. and Al-Mazrooei, F.M. (2007). Bank's risk management: A comparison study of UAE national and foreign banks. Journal of Risk Finance, 8(4), 394-409. https://doi.org/10.1108/15265940710777333

Angelini, E., Tolly, D.D. and Roli, A. (2008). A neutral network approach for credit risk evaluation. The Quarterly Review of Economics and Finance, 48(4), 733-755. https://doi.org/10.1016/j.qref.2007.04.001

Apostolik, R., Donohue, C., and P. Went. (2009). Foundations of Banking Risk, Wiley Finance, New Jersey.

Baumann, U. and Erlend, N. (2004), Disclosure, volatility, and transparency: an empirical investigation into the value of bank disclosure. Federal Reserve Bank of New York Economic Policy Review, 10(2), 31-45, 78.

Bennis, W., and O'Toole, J. (2009). A culture of candor. Harvard Business Review. 
Bertay, A.C., Demirgüç-Kunt, A., Huizinga, H., (2013). Do we need big banks? Evidence on performance, strategy and market discipline. Journal of Financial Intermediation 22(4), 532-558. https://doi.org/10.1016/j.jfi.2013.02.002

Bonfim, D., and M. Kim. (2012). Liquidity risk in banking: is there herding?, Working Paper

Botosan, C. A. and Plumlee, M. A. (2002), A Re-examination of Disclosure Level and the Expected Cost of Equity Capital. Journal of Accounting Research, 40, 21-40. https://doi.org/10.1111/1475-679X.00037

Bushee, B.J., and Noe, C.F. (2000). Corporate Disclosure Practices, Institutional Investors and Stock Return Volatility. Journal of Accounting Research, 38(3), 171-202. https://doi.org/10.2307/2672914

Cordella, T. and Eduardo Levy Yeyati E.L., (1998). Public Disclosure and Bank Failures. IMF Staff Papers, 45(1), 110-131. https://doi.org/10.2307/3867331

Fischer, S. (1999). Reforming the international financial system. The Economic Journal, 109, 557-76. https://doi.org/10.1111/1468-0297.00472

Fung, B., (2014). The Demand and Need for Transparency and Disclosure in Corporate Governance. Universal Journal of Management, 2(2), 72-80.

Gilbert, R.A. \& Vaughan, M.D. (1998), Does the publication of supervisory enforcement actions add to market discipline? Research in Financial Services: Public and Private Policy, $10,259-80$

Gorton, G, and Huang, L. (2006). Bank panics and the endogeneity of central banking. $\begin{array}{llll}\text { Journal of Monetary } & \text { Economics } & \text { 53(7), }\end{array}$ https://doi.org/10.1016/j.jmoneco.2005.05.015

Habibullah and Ghosh (1986). Risk Management: A study of Bangladesh Jute Mills corporation and Bangladesh textile corporation. Bureau of Business Research, University of Dhaka.

Hassan, O., Marston, C. (2010). Disclosure measurement in the empirical accounting literature - a review article. Accountancy Discussion Papers 1004, Accountancy Research Group, Heriot Watt University

Healy, P. M., \& Palepu, K. G., (2001). Information asymmetry, corporate disclosure, and the capital markets: a review of the empirical disclosure literature. Journal of Accounting and Economics, 31(1-3), 405-440. https://doi.org/10.1016/S0165-4101(01)00018-0

Hitchins, J., Mallett, D. and Hogg, H. (2001). Banking: An industry Accounting and Auditing Guide, London: Institute of Chartered Accountants in England and Wales.

Hyytinen, Ari, Kuosa, Iikka and Takalo, Tuomas, (2003), Law or Finance: Evidence from Finland. European Journal of Law and Economics, 16(1), 59-89. https://doi.org/10.1023/A:1023932325783

Jensen, M., and Meckling, W. (1976). Theory of the firm: managerial behavior, agency costs 
and ownership structure. Journal of Financial Economics 3(4), 305-360. https://doi.org/10.1016/0304-405X(76)90026-X

Jorion, P. (2003). Financial risk manager handbook. 2nd ed., New York, Chichester: Wiley.

Kaufman, G.G., Scott, K.E., (2003). What is systemic risk and do bank regulators retard or contribute to it? Independent Rev. VII, 372-391.

Lajili, K \&Zéghal, D (2005), A content analysis of risk management disclosures in Canadian annual reports. Canadian Journal of Administrative Sciences, 22(2), 125-142. https://doi.org/10.1111/j.1936-4490.2005.tb00714.x

Lin, S.L. (2009). A new two stage hybrid approach of credit risk in banking industry. Expert Systems with Applications, 36(4), 8333-8341. https://doi.org/10.1016/j.eswa.2008.10.015

Linsley, PM \& Shrives, PJ (2005), Examining risk reporting in UK public companies. Journal of Risk Finance, 6(4), 292-305. https://doi.org/10.1108/15265940510613633

Linsley, PM \& Shrives, PJ (2005b), Transparency and the disclosure of risk information in the banking sector. Journal of Financial Regulation and Compliance, vol. 13(3), 205-214. https://doi.org/10.1108/13581980510622063

Nier, E., and Baumann, U., (2006). Market discipline, disclosure and moral hazard in banking. Journal of Financial Intermediation, 15, 332-361. https://doi.org/10.1016/j.jfi.2006.03.001

Nier, Erlend W., (2005). Bank stability and transparency. Journal of Financial Stability, 1, 342-354. https://doi.org/10.1016/j.jfs.2005.02.007

Oliveira, J., Rodrigues, L. L. And Craig, R. (2011) Risk-related disclosure practices in the annual reports of Portuguese credit institutions: An exploratory study. Journal of Banking Regulation, 12(2), 100-118. https://doi.org/10.1057/jbr.2010.20

Poskitt, R. (2005), Disclosure regulation and information risk. Accounting \& Finance, 45, 457-477. https://doi.org/10.1111/j.1467-629X.2005.00147.x

Richard, E., Chijoriga, M., Kaijage, E., Peterson, C. and Bohman, H. (2008). Credit risk management system of a commercial bank in Tanzania. International Journal of Emerging Markets, 3(3), 323-332. https://doi.org/10.1108/17468800810883729

Saunders, M., Lewis, P., \& Thornhill, A. (2009). Research Methods for Business Students, 5th edition, Prentice Hall

Tadesse, S. (2006). The economic value of regulated disclosure: Evidence from the banking sector. Journal of Accounting and Public Policy, 25, 32-70. https://doi.org/10.1016/j.jaccpubpol.2005.11.002

Van Greuning, Hennie; BrajovicBratanovic, Sonja. (2003). Analyzing and Managing Banking Risk: A Framework for Assessing Corporate Governance and Financial Risk Management, Second Edition. Washington, DC: World Bank. (C) World Bank. https://doi.org/10.1596/0-8213-5418-3 
Notes

Note 1. Mohammad Habibullah and Santi Narayan Ghosh in their books "Risk Management" define the risk along with classifications. The book published in 1986 under Bureau of Business Research, Dhaka University Press.

Note 2. Bangladesh Bank, the central bank and apex regulatory body for the country's monetary and financial system, was established in Dhaka as a body corporate vide the Bangladesh Bank Order, 1972 (P.O. No. 127 of 1972) with effect from 16 December 1971.

Note 3. The legislative framework applied in the form of memorandum of understanding (MOU) with the directives of Bangladesh Bank (DOBB) that are considered as the low performer banks in terms of asset quality, capital adequacy and weak governance systems. These banks are required special attention and supervision by the regulatory bodies in upgrading their performance.

Note 4. The newly established banks that got license in 2013 and operated in Bangladesh as schedule banks except one Islamic bank that are included in Group 3.

Note 5. The risk arises from the change of the value of cash flows with regard to change of the real interest rate. In fact, it indicates the mismatch of cash flows maturities by the ends of decreasing financial earnings.

Note 6. The current and forthcoming effect on banks' earnings that is deliberately initiated by the unpredicted movements of currency exchange rates.

Note 7 . The probable losses are arising from the change in equity price.

Note 8 . Credit spread is measured by the variance of Treasury bond yield and debt security yield with uniform maturity periods but have lesser quality.

Note 9. The uncertainty arising from the price movement that is negatively affected the financial results of those who are the producer and consumer at the same time. 


\section{Appendix}

A-1: Group-wise dissection of Credit Risk in the Banking System

\begin{tabular}{cllcc}
\hline Year & Bank Group & Description of the group & $\begin{array}{c}\text { Share in } \\
\text { industry } \\
\text { credit risk } \\
(\%)\end{array}$ & $\begin{array}{c}\text { Share in } \\
\text { industry } \\
\text { overall risk } \\
(\%)\end{array}$ \\
\hline & & & 52.4 & 45.7 \\
& & & 20.6 & 17.9 \\
& Group 1 & Private commercial banks & 18.2 & 15.9 \\
& Group 2 & State-owned and Private commercial banks under special attention & 5.3 & 4.7 \\
& Group 3 & Full-fledge Islamic Private commercial banks & 3.5 & 3 \\
\hline & Group 4 & Foreign Commercial Banks & 52.1 & 45 \\
& Group 5 & Fourth Generation Private Commercial Banks & 21.7 & 18.8 \\
& Group 1 & Private commercial banks & 17.7 & 15.4 \\
& Group 2 & State-owned and Private commercial banks under special attention & 5.7 & 4.9 \\
& Group 3 & Full-fledge Islamic Private commercial banks & 2.8 & 2.4 \\
\hline Group 4 & Foreign Commercial Banks & 51.6 & 44.2 \\
& Group 5 & Fourth Generation Private Commercial Banks & 22.9 & 19.6 \\
& Group 1 & Private commercial banks & 17.4 & 14.9 \\
& Group 2 & State-owned and Private commercial banks under special attention & 6.5 & 5.6 \\
2014 & Group 3 & Full-fledge Islamic Private commercial banks & 1.6 & 1.4 \\
\hline
\end{tabular}

Source: Financial Stability Report (2014-2016), Bangladesh Bank

A-2: Market risk under Basel III: From the Year 2010-2016

\begin{tabular}{cccc}
\hline Year & Market Risk & Other Risk & Total \\
\hline 2010 & 7 & 93 & 100 \\
2011 & 6.2 & 93.8 & 100 \\
2012 & 5.2 & 94.8 & 100 \\
2013 & 6 & 94 & 100 \\
2014 & 5.3 & 94.7 & 100 \\
2015 & 4.5 & 95.5 & 100 \\
2016 & 3.8 & 96.2 & 100 \\
\hline
\end{tabular}

A-3: Market risk components under Basel III: From the Year 2010-2016

\begin{tabular}{ccccc}
\hline Year & Equity Risk & Interest Rate Risk & FX Position Risk & Total \\
\hline 2010 & 62.7 & 27.8 & 9.5 & 100 \\
2011 & 52.1 & 21.1 & 26.8 & 100 \\
2012 & 63.4 & 20.2 & 16.4 & 100 \\
2013 & 56.6 & 26.1 & 17.3 & 100 \\
2014 & 49.5 & 32.2 & 18.3 & 100 \\
2015 & 48.7 & 32.7 & 18.6 & 100 \\
2016 & 48.8 & 32.7 & 18.5 & 100 \\
\hline
\end{tabular}


A-4: Market risk Components: Top 5 Banks

\begin{tabular}{|c|c|c|c|c|c|c|c|c|c|}
\hline \multicolumn{4}{|c|}{ IRR in the Banking System } & \multicolumn{3}{|c|}{ ERR in the Banking System } & \multicolumn{3}{|c|}{ EPR in the Banking System } \\
\hline Year & $\begin{array}{c}\text { Interest } \\
\text { Rate Risk } \\
\text { (IRR) }\end{array}$ & $\begin{array}{c}\text { Share in } \\
\text { Market } \\
\text { Risk }\end{array}$ & $\begin{array}{c}\text { Share in } \\
\text { Overall } \\
\text { Risk }\end{array}$ & $\begin{array}{l}\text { Exchange } \\
\text { Rate Risk }\end{array}$ & $\begin{array}{c}\text { Share in } \\
\text { market } \\
\text { risk }\end{array}$ & $\begin{array}{c}\text { Share in } \\
\text { overall } \\
\text { risk }\end{array}$ & $\begin{array}{c}\text { Equity } \\
\text { Price } \\
\text { Risk }\end{array}$ & $\begin{array}{c}\text { Share in } \\
\text { market } \\
\text { risk }\end{array}$ & $\begin{array}{c}\text { Share in } \\
\text { overall } \\
\text { risk }\end{array}$ \\
\hline 2010 & 46 & 36 & 13 & 45 & 4 & 0.3 & 47 & 30 & 2.2 \\
\hline 2011 & 43.4 & 9.1 & 0.6 & 71.1 & 19 & 1.2 & 37.8 & 19.7 & 1.2 \\
\hline 2012 & 45.6 & 9.2 & 0.5 & 46.2 & 7.6 & 0.4 & 45.3 & 28.7 & 1.5 \\
\hline 2013 & 67.6 & 16.4 & 1 & 56.8 & 10.5 & 0.6 & 48.6 & 30.2 & 1.8 \\
\hline 2014 & 46.7 & 15 & 0.8 & 50.9 & 9.3 & 0.5 & 44.5 & 22 & 1.2 \\
\hline 2015 & 53.2 & 17.4 & 0.8 & 51.9 & 9.6 & 0.4 & 41.7 & 20.3 & 0.9 \\
\hline 2016 & 67 & 21.9 & 0.9 & 48.4 & 9 & 0.4 & 38.1 & 18.6 & 0.7 \\
\hline
\end{tabular}

A-5: Market risk Components: Top 10 Banks:

\begin{tabular}{|c|c|c|c|c|c|c|c|c|c|}
\hline & \multicolumn{3}{|c|}{ IRR in the Banking System } & \multicolumn{3}{|c|}{ ERR in the Banking System } & \multicolumn{3}{|c|}{ EPR in the Banking System } \\
\hline Year & $\begin{array}{c}\text { Interest } \\
\text { Rate } \\
\text { Risk }\end{array}$ & $\begin{array}{c}\text { Share in } \\
\text { Market } \\
\text { Risk }\end{array}$ & $\begin{array}{c}\text { Share in } \\
\text { Overall } \\
\text { Risk }\end{array}$ & $\begin{array}{l}\text { Exchange } \\
\text { Rate Risk }\end{array}$ & $\begin{array}{c}\text { Share in } \\
\text { market } \\
\text { risk }\end{array}$ & $\begin{array}{c}\text { Share in } \\
\text { overall } \\
\text { risk }\end{array}$ & $\begin{array}{c}\text { Equity } \\
\text { price } \\
\text { risk }\end{array}$ & $\begin{array}{c}\text { Share in } \\
\text { market } \\
\text { risk }\end{array}$ & $\begin{array}{c}\text { Share in } \\
\text { overall } \\
\text { risk }\end{array}$ \\
\hline 2010 & 69 & 38 & 19 & 62 & 6 & 0.4 & 72 & 45 & 3.3 \\
\hline 2011 & 67.6 & 14.3 & 0.9 & 81.8 & 21.9 & 1.4 & 50.9 & 26.5 & 1.6 \\
\hline 2012 & 72 & 14.5 & 0.7 & 67.8 & 11.1 & 0.6 & 69.6 & 44.2 & 2.3 \\
\hline 2013 & 94.9 & 23 & 1.4 & 72.1 & 13.3 & 0.8 & 71 & 44.2 & 2.6 \\
\hline 2014 & 68.8 & 22.1 & 1.1 & 69.4 & 12.7 & 0.7 & 68.6 & 33.9 & 1.8 \\
\hline 2015 & 72.1 & 23.6 & 1.1 & 67.5 & 12.5 & 0.6 & 67.3 & 32.8 & 1.5 \\
\hline 2016 & 83.7 & 27.4 & 1.1 & 64.6 & 11.9 & 0.5 & 59.5 & 29 & 1.1 \\
\hline
\end{tabular}

A-6: Operational Risk under Basel III: From the Year 2010-2016

\begin{tabular}{lcc|cc}
\hline & \multicolumn{2}{c|}{ Top 5 Banks } & \multicolumn{2}{c}{ Top 10 Banks } \\
\hline Year & $\begin{array}{c}\text { Share in industry } \\
\text { operational Risk }\end{array}$ & $\begin{array}{c}\text { Share in industry } \\
\text { overall risk }\end{array}$ & $\begin{array}{c}\text { Share in industry } \\
\text { operational Risk }\end{array}$ & $\begin{array}{c}\text { Share in industry } \\
\text { overall risk }\end{array}$ \\
\hline $\mathbf{2 0 1 0}$ & 29 & 2.3 & 46 & 3.8 \\
$\mathbf{2 0 1 1}$ & 30.6 & 2.6 & 48.2 & 4.2 \\
$\mathbf{2 0 1 2}$ & 30.6 & 2.4 & 47.7 & 4.4 \\
$\mathbf{2 0 1 3}$ & 24.5 & 2.2 & 35.1 & 3.1 \\
$\mathbf{2 0 1 4}$ & 28.2 & 2.5 & 45.9 & 4.1 \\
$\mathbf{2 0 1 5}$ & 28.5 & 2.6 & 45.4 & 4.1 \\
$\mathbf{2 0 1 6}$ & 27.5 & 2.5 & 44.4 & 4 \\
\hline
\end{tabular}

\section{Copyright Disclaimer}

Copyright for this article is retained by the author(s), with first publication rights granted to the journal.

This is an open-access article distributed under the terms and conditions of the Creative Commons Attribution license (http://creativecommons.org/licenses/by/3.0/). 